\title{
SheddomeDB: the ectodomain shedding database for membrane-bound shed markers
}

\author{
Wei-Sheng Tien ${ }^{1,2}$, Jun-Hong Chen ${ }^{3}$ and Kun-Pin $\mathrm{Wu}^{1 *}$ \\ From The Fifteenth Asia Pacific Bioinformatics Conference \\ Shenzhen, China. 16-18 January 2017
}

\begin{abstract}
Background: A number of membrane-anchored proteins are known to be released from cell surface via ectodomain shedding. The cleavage and release of membrane proteins has been shown to modulate various cellular processes and disease pathologies. Numerous studies revealed that cell membrane molecules of diverse functional groups are subjected to proteolytic cleavage, and the released soluble form of proteins may modulate various signaling processes. Therefore, in addition to the secreted protein markers that undergo secretion through the secretory pathway, the shed membrane proteins may comprise an additional resource of noninvasive and accessible biomarkers. In this context, identifying the membrane-bound proteins that will be shed has become important in the discovery of clinically noninvasive biomarkers. Nevertheless, a data repository for biological and clinical researchers to review the shedding information, which is experimentally validated, for membrane-bound protein shed markers is still lacking.
\end{abstract}

Results: In this study, the database SheddomeDB was developed to integrate publicly available data of the shed membrane proteins. A comprehensive literature survey was performed to collect the membrane proteins that were verified to be cleaved or released in the supernatant by immunological-based validation experiments. From 436 studies on shedding, 401 validated shed membrane proteins were included, among which 199 shed membrane proteins have not been annotated or validated yet by existing cleavage databases. SheddomeDB attempted to provide a comprehensive shedding report, including the regulation of shedding machinery and the related function or diseases involved in the shedding events. In addition, our published tool ShedP was embedded into SheddomeDB to support researchers for predicting the shedding event on unknown or unrecorded membrane proteins.

Conclusions: To the best of our knowledge, SheddomeDB is the first database for the identification of experimentally validated shed membrane proteins and currently may provide the most number of membrane proteins for reviewing the shedding information. The database included membrane-bound shed markers associated with numerous cellular processes and diseases, and some of these markers are potential novel markers because they are not annotated or validated yet in other databases. SheddomeDB may provide a useful resource for discovering membrane-bound shed markers. The interactive web of SheddomeDB is publicly available at http://bal.ym.edu.tw/SheddomeDB/.

Keywords: Ectodomain shedding, Biomarker discovery, Shed membrane proteins, Sheddome

\footnotetext{
* Correspondence: kpwu@ym.edu.tw

${ }^{1}$ Institute of Biomedical Informatics, National Yang Ming University, Taipei

112, Taiwan

Full list of author information is available at the end of the article
} International License (http://creativecommons.org/licenses/by/4.0/), which permits unrestricted use, distribution, and reproduction in any medium, provided you give appropriate credit to the original author(s) and the source, provide a link to the Creative Commons license, and indicate if changes were made. The Creative Commons Public Domain Dedication waiver (http://creativecommons.org/publicdomain/zero/1.0/) applies to the data made available in this article, unless otherwise stated. 


\section{Background}

A large class of proteins is known to be secreted from the cell to the extracellular space. The secreted proteins such as hormones, enzymes, and antibodies play vital regulatory roles in biological signaling and may serve as clinically noninvasive biomarkers and potential therapeutic targets $[1,2]$. In addition to the proteins that undergo protein secretion via secretory pathways, membrane proteins are known to be released into the extracellular milieu via ectodomain shedding. Certain membrane-bound proteins, including cell adhesion molecules, growth factors, cytokines, and cell receptors, can be proteolytically cleaved by sheddase that results in the release of soluble forms of fragments. The process of ectodomain shedding has been shown to regulate various pathologies and diseases such as degeneration, inflammation, and cancer and physiological processes such as proliferation, differentiation, and migration [3, 4]. In this context, the cleaved and released membrane proteins resulting from shedding events may comprise additional resources of valuable secreted and soluble biomarkers for pathological states or physiological conditions.

Previous studies on membrane proteins revealed that only about 2 or $4 \%$ of cell surface molecules undergo the shedding process $[5,6]$; hence, it is apparent that not every membrane protein will be released through proteolytic shedding. Therefore, to assess whether a membranebound protein will be released from cells and to identify membrane-bound shed markers that are of clinical potential, a data repository dedicated to provide shedding information that is experimentally validated for membrane proteins seems indispensable. Although cleavage databases such as MEROPS [7], PMAP-SubstrateDB [8], and HPRD [9] have been developed as information resources for proteases, substrates, and cleavage events, a portion of cleavage records collected by the databases may be based on library-based approaches for identification of protease cleavage sites $[10,11]$, and the putative substrates identified in the original literature may not be validated or physiologically relevant. In addition, currently, some shed membrane proteins that were identified by shedding studies may not have yet been recorded and annotated in these cleavage databases.

In this context, the database SheddomeDB was designed for the identification of shed membrane proteins that are released through proteolytic cleavage. The membrane proteins that were verified to be cleaved or released in the supernatant by immunological-based validation experiments were included in our database. Based on a comprehensive literature survey on shedding event studies, a total of 401 validated shed membrane proteins were identified, among which 199 shed membrane proteins have not been annotated or validated yet by current cleavage databases. SheddomeDB also provides a user-friendly web interface for researchers to search or browse proteins of interest. For each experimentally validated shed membrane protein, SheddomeDB attempted to provide a comprehensive shedding report based on literature references, including the regulation of shedding machinery and the related function or diseases involved in the shedding events. The cross-references to other resources, such as the released evidence in secretome data and the existing records of protease cleavage sites, were provided in SheddomeDB as well. In addition, the previously published prediction tool ShedP [12] was embedded into SheddomeDB. ShedP is a computational method developed to predict the shedding event on membrane proteins based on the protein sequence. By incorporating a prediction web interface for ShedP, SheddomeDB also supports the researchers for the assessment of shedding events on the unknown or unrecorded membrane proteins.

Thus, by collecting experimentally validated shed membrane proteins from literature references, SheddomeDB may provide a useful resource of membrane-bound shed markers associated with numerous cellular processes and diseases, including some potential novel markers that are not annotated or validated yet in other databases. SheddomeDB may be a useful bioinformatics design in sheddome marker discovery and to help investigate the regulatory role of membrane proteins in physiological and pathological processes. SheddomeDB is publicly available at http://bal.ym.edu.tw/SheddomeDB/.

\section{Methods}

\section{Database implementation and interface design}

The MYSQL relational database version 5.0.45 (http:// www.mysql.com) was used in the current study to design and construct the SheddomeDB database and the interactive web interface. A JAVA-based model-view-controller (MVC) framework was utilized for the web interface to separate the logic, application, and the presentation into three distinct layers. All the interactions between the web client requests and the server side were handled by Apache web server. The dynamic web pages were designed using JavaServer Pages (JSP) and Cascading Style Sheets (CSS), and the user-interactive pages were supported by JavaScript and its library jQuery for client-side scripting.

\section{Data source}

A comprehensive literature survey was conducted to identify the membrane proteins that were experimentally validated to be cleaved or released into the supernatant. By searching the PubMed database using the following keywords: "shedding", "proteolytic", "cleavage", "protease", "soluble form" and "released" the relevant studies on membrane protein shedding or protease cleavage were first acquired. We further manually reviewed the published studies and screened for the validated shed 
membrane proteins based on the following selection criteria: (1) The membrane proteins were verified to be cleaved by protease and protease inhibitors or the release of the soluble forms of proteins was detected in the culture supernatant. (2) The shedding events of membrane proteins were validated by antibody-based probes against the endogenous protein or against stably expressed genes encoding the protein. The curated publications that met the screening criteria were further selected as the data source to collect all the relevant data on membrane protein shedding. We mapped the membrane proteins in each curated publication to the UniProtKB/Swiss-Prot database [13] to uniform the protein ID based on the protein name and the organism source of the protein. In addition, because the functional consequences of membrane protein shedding can be diverse and depend on the protein function or the shed form of fragments, we grouped each shed membrane protein into functional categories based on the regulated functions or diseases suggested in the shedding literature. If the functional consequences of protein shedding were not clarified in the original studies, the shed membrane protein was then categorized based on the function description or annotation in the UniProtKB/Swiss-Prot database.

\section{Incorporated shedding predictor ShedP}

The in-house prediction tool ShedP previously developed to predict shedding events of membrane proteins was incorporated into the SheddomeDB database. ShedP is a support vector machine (SVM)-based model [14] built by supervised machine learning that discriminates between shed membrane proteins and nonshed membrane proteins. The SVM model based on PseAAC [15] feature representation was constructed as our ShedP tool after a 5-fold cross-validation training procedure. At present, ShedP is the computational method published to predict shedding events of membrane proteins. To support the researchers for assessing the likelihood of an unknown or unrecorded membrane protein to be cleaved and released from the cell, we have also integrated a web interface to the prediction by ShedP into the SheddomeDB database, enabling valuable hints to be gained by in silico prediction.

\section{Results and Discussion}

\section{Database content}

In the present study, 436 curated studies were selected based on our literature survey process [3, 16-450], and a total of 401 validated shed membrane proteins were collected. Among the shed membrane proteins included in SheddomeDB, 22 proteins have not yet been annotated by existing cleavage databases MEROPS, PMAP-SubstrateDB, and HPRD. In addition, among those identified membrane proteins that have already been recorded in cleavage databases, 28 membrane proteins were only shown to undergo cleavage by signal peptidase [451-462] and 149 membrane proteins were only referenced by one substrate specificity study using a computational prediction model [463]. The cleavage records of membrane proteins in these studies may be neither relevant to membrane protein shedding nor experimentally validated. Therefore, our results revealed that a total of 199 shed membrane proteins in SheddomeDB were not annotated or validated yet by other cleavage databases. The details of the identified shed membrane proteins and the reference studies are summarized in (Additional file 1: Table S1).

Because the process of proteolytic shedding has been shown to be involved in various physiological processes and diseases, it is of importance to know which biological function categories or diseases may be regulated or related to the shedding of membrane proteins. Thus, we further grouped the validated shed membrane proteins into function categories manually based on the functional consequences referenced by shedding studies or functional description in the UniProtKB/Swiss-Prot database. First, the shed membrane proteins were grouped into the category "disease" if the proteins were shown to be involved in the disease progression or suggested as disease marker candidates. For instance, the shedding events of the proteins CDH1, EFNA1, and SDC1 were suggested to be involved in cancer invasion and immune escape [16-20]; the shedding events of SNCA and APP were shown to be involved in neurodegenerative disorders such as Parkinson's disease and Alzheimer's disease [21-23]; the shedding event of NRP2 was involved in immune disorders such as rheumatoid arthritis [24]; that of SDC4 was suggested to be involved in cardiovascular diseases such as atrial fibrillation [25]; HAVCR2 shedding event being implicated in HIV infection [26]; and the shedding event of CADM1 was shown to be involved in diabetes [27, 28]. In addition, several shed or soluble membrane proteins were suggested to be marker candidates for cancers (e.g., PVRL4 [29], CD200 [30, 31], CDH17 [32]), atherosclerosis (e.g., SORL1 [33-36]), diabetes mellitus (e.g., CLEC1B [37]), neurodegenerative disorders (e.g., PDGFRB [38, 39]), and hepatocyte damage (e.g., PTPRG [40]).

Then, a large portion of the shed membrane proteins were found to be related to immune response or neural signaling and were categorized into "immune and inflammation" or "central nervous system," respectively. For instance, the shedding of numerous cytokines, cell receptors, and cell adhesion molecules was shown to be involved in leukocyte recruitment (e.g., CXCL16 [23, 41, 42], CDH5 [23, 41], TNFRSF8 [41, 43]), T-cell proliferation (e.g., Lag3 [41, 44]), and other immunological modulations (e.g., CR2 [45]). In contrast, the shedding of cell adhesion molecules, ligands, and cell receptors was involved in axon 
guidance (e.g., Epha4 [46], Neo1 [47]) and neurite outgrowth (e.g., NCAM1 [48-50]). In addition, another group of shed membrane proteins were found to be specifically related to the cardiovascular system and were further categorized into "angiogenesis" or "blood and homoeostasis." For instance, the shedding of the proteins JAM3 and CLEC14A was suggested to be involved in the regulation of angiogenesis [51, 52], and the shedding of the proteins GP1BA and GP5 was suggested to be involved in the regulation of platelet hemostasis $[23,53]$.

For the remaining shed membrane proteins, most of the growth factors (e.g., BTC $[23,54,55])$, growth factor receptors (e.g., NGFR $[56,57])$, morphogens (e.g., SHH [58]), and cell adhesion molecules (e.g., EPCAM $[59,60]$ ) were shown to be involved in cell proliferation, migration, and morphogenesis and were categorized into "cell growth and development." In addition, some shed proteins were found to be related to metabolism and were grouped into "lipid" (e.g., DLK1 [61, 62]), "melanogenesis" (e.g., PMEL [63]), "insulin" (e.g., TMEM27 $[64,65]$ ), and "renal" (e.g., UMOD [66]). In addition, others were found to be related to protein function and were grouped into "enzyme" (e.g., ACE [67]), "transporter" (e.g., FOLR1 [68]), and "cell surface structure" (e.g., DSG2 [69]). Finally, we found some proteins that were specifically related to "aging" (e.g., KL [70, 71]). Thus, as depicted in Fig. 1, the 401 identified shed membrane proteins were grouped into 14 categories; the details of the protein members in each function category are summarized in (Additional file 1: Table S2) and can be reviewed in our browsed pages.

\section{User querying and web interface}

SheddomeDB provided a user-friendly web interface for researchers to search or browse proteins of interest. To query the database, the researchers can begin the search task from the "Search" page in which two query options were provided (Fig. 2). First, the database can be queried by directly specifying the protein UniProt ID. In contrast, the researchers can make a text similarity query by inputting the protein name or gene symbol and specify the desired one from all possible protein candidates in the interactive page. In addition, the researchers can choose the "Browse" page to browse the membrane proteins based on function categories (the disease or function categories involved in or related to shedding process) (Fig. 2).

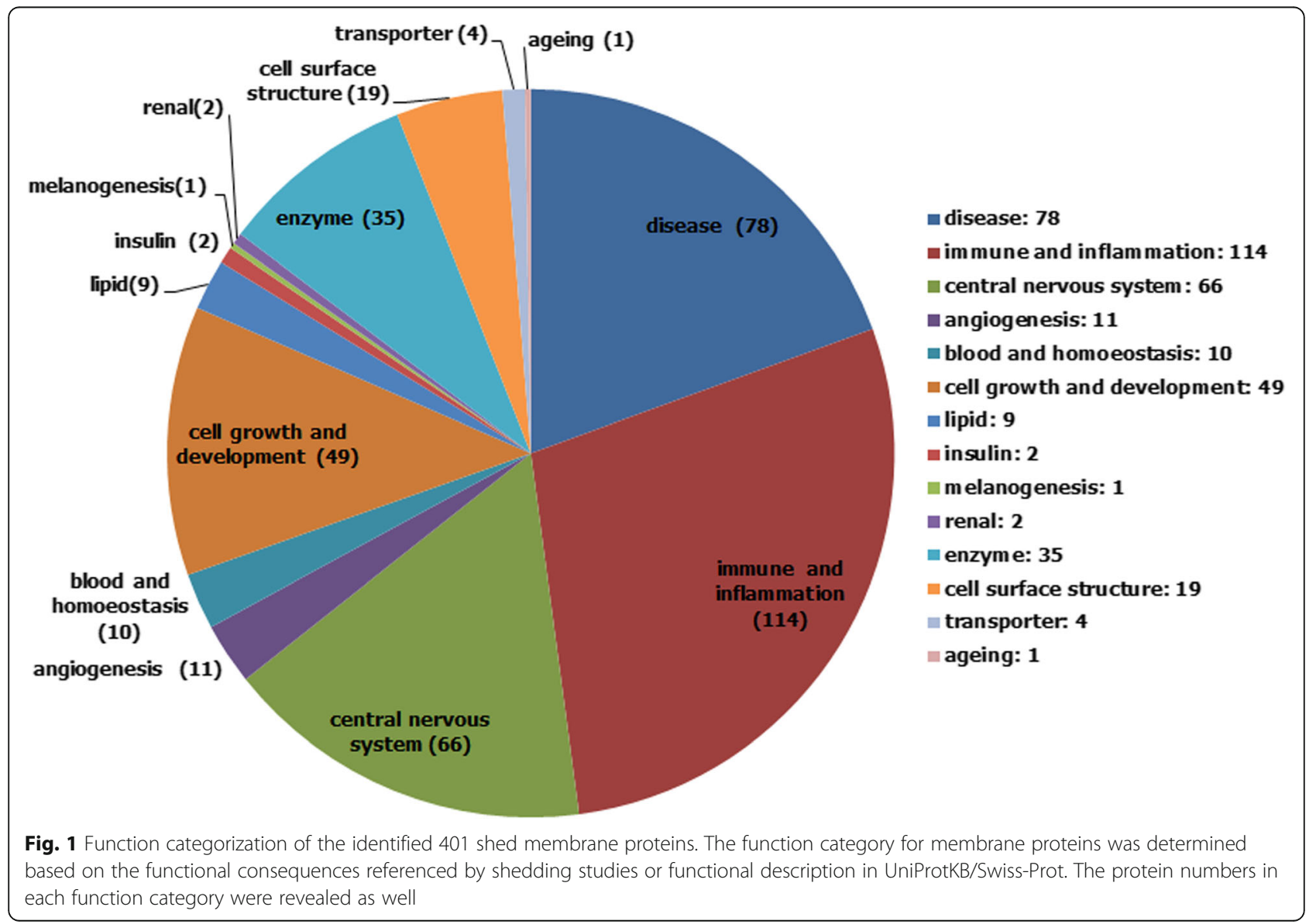




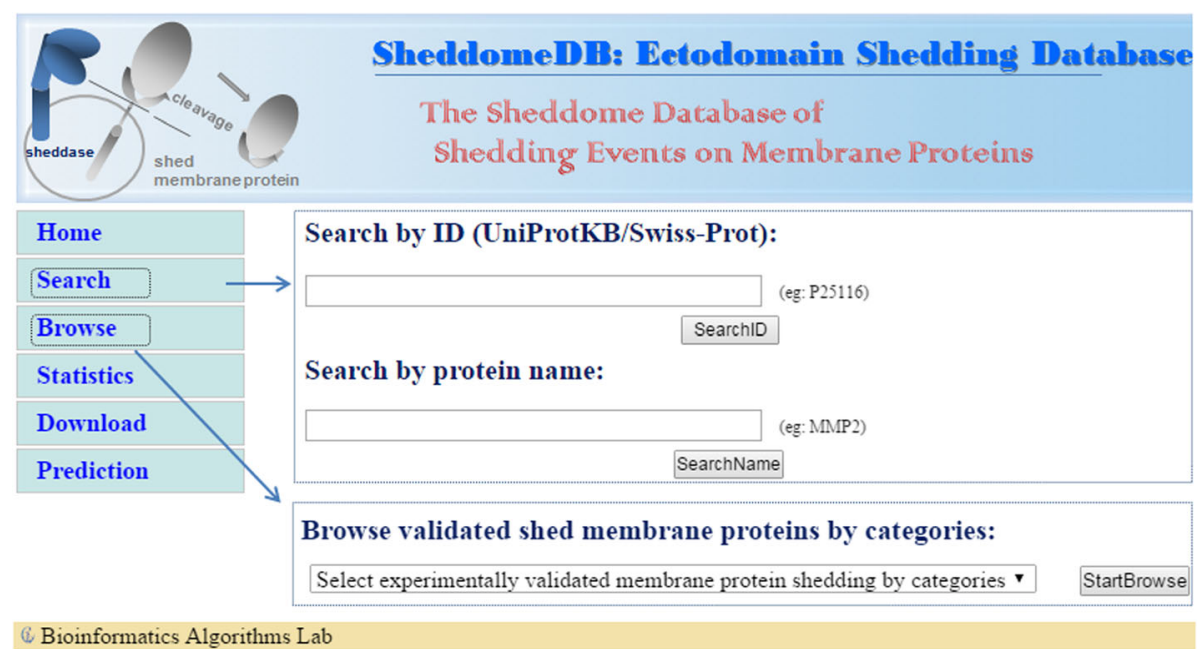

Fig. 2 The interactive web interface of SheddomeDB. SheddomeDB provided a user-friendly web interface to query the database. The users can either search proteins of interest from the "Search" page or browse all shed membrane proteins from the "Browse" page

In the results pages for each experimentally validated shed membrane protein, a comprehensive shedding report was provided by SheddomeDB in four sections (Fig. 3), as follows: (i) In section A, the basic information such as protein name, gene symbol, organism, and extracellular region were referenced from the UniProtKB/ Swiss-Prot database. In addition, the membrane protein type annotated from UniProtKB/Swiss-Prot was also provided to show whether the membrane protein is (1.) lipid or GPI-anchored, (2.) topological (with extracellular and transmembrane domain, (3.) cell membrane annotated (annotated localized in cell membranes), and (4) other membrane proteins (proteins annotated at other subcellular localizations). (ii) The cross-references to the secretome released information were revealed in section $B$. If the query proteins were annotated to be released by secretome studies [72-74, 464-466] or by the secreted protein datasets in the databases the secretome databases HCSD [467] and Sys-BodyFluid [468], the secreted protein database SPD [469], and the subcellular localization database LOCATE [470], the secretome information such as the secretome database, secreted cell type, the reference PubMed ID, and the protein ID used in the reference literature will be summarized and provided. (iii) In section $C$, the regulation of the shedding machinery, the related function or disease, the protease name, and the PubMed ID of the shedding reference were summarized. (iv) In section D, the cross-references to existing cleavage sites records from current cleavage databases MEROPS, PMAP-SubstrateDB, and HPRD were provided. The cleavage information such as the cleavage database, protease name, reference PubMed ID, the cut location, and the cut sequence motif were provided. In addition, the protein sequence structure was represented in which the extracellular domain region and the protease cleavage site can be visualized.

\section{ShedP prediction interface}

SheddomeDB incorporated a web interface to prediction by ShedP so as to gain valuable hints by in silico prediction. By inserting the protein sequence of a queried protein, the users can assess the likelihood of an unknown or unrecorded membrane protein to be cleaved and released from the cell. Based on the prediction model, a query protein whose predicted probability was greater than or equal to 0.5 was regarded as positive and predicted to be shed, otherwise it was predicted as negative and nonshed (Fig. 4).

\section{Conclusions}

As more and more studies have revealed the regulatory role of ectodomain shedding in various cellular processes and pathologies, the identification of shed and released membrane proteins is becoming important in the field of biomarker discovery and sheddome proteomics. To determine and assess the possible membrane protein candidates undergoing shedding and released from the cells, the database SheddomeDB is the first sheddome-based database developed to store and query publicly available data on shed membrane proteins. For each queried membrane protein, SheddomeDB provides the researchers comprehensive cross-references including the released evidence in the secretome, protease cleavage record, and biologically validated shedding report. Thus, the bioinformatics-based database SheddomeDB may serve as a useful resource for membranebound secreted markers. 


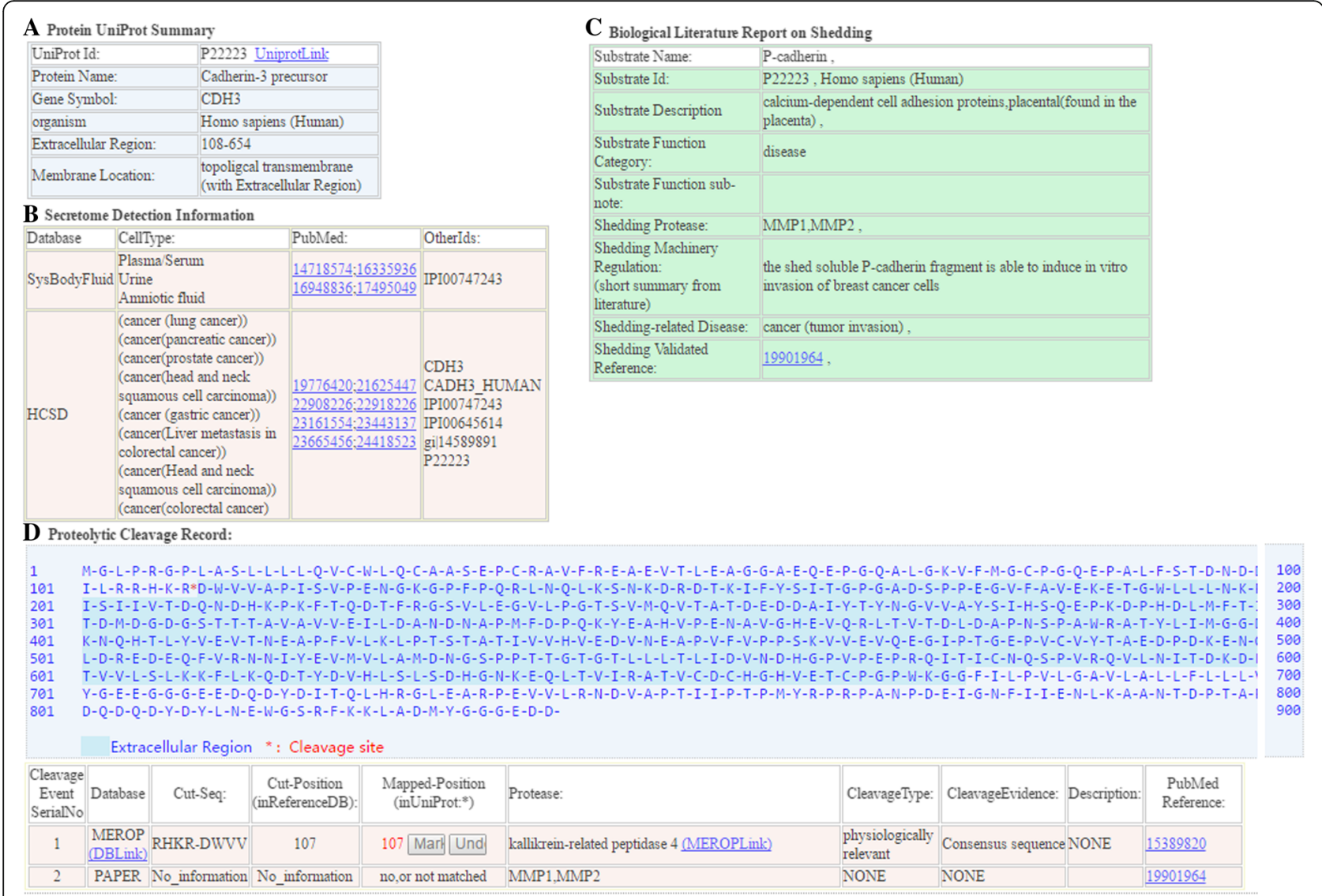

Fig. 3 Example of SheddomeDB result pages. For each query membrane protein, the information was provided in four sections in the result pages. Section A revealed the basic protein information from UniProtKB/Swiss-Prot. Section B provided secretome released information. Section C summarized the biological information from the biologically validated literature on the shedding process. Section D provided existing cleavage site information. The protein sequence structure was depicted as well, in which the extracellular domain regions are marked with blue color and each protease cleavage site is labeled with an asterisk

\begin{tabular}{|l|}
\hline Home \\
\hline Search \\
\hline Browse \\
\hline Statistics \\
\hline Download \\
\hline Prrediction: : \\
\hline
\end{tabular}

Paste protein sequence(s) with FASTA format.

>protein_1 MSSAPDPPTVKKEPLKEKNFENPGLRGAHTTTLFRAVNPELFIKPNKPVMAFGLVTLSLCVAYIGYLHA TQENRKDLYEAIDSEGHRYMRRKTSKWD

>protein_2

MNWKVLEHVPLLLYYILAAKTLILCLTFAGVKMYQRKRLEAKQQKLEAERKKQSEKKDN

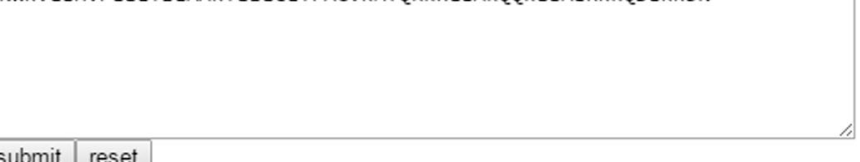

$\sqrt{4}$

PROTEIN SHEDDING PREDICTION PAGE : (The page will refresh every 10 secs until task finished)

\begin{tabular}{|c|c|c|c|}
\hline Protein name & ShedP value & ShedP results \\
\hline protein_1 & 0.712132 & undergo proteolytic shedding (ShedP value $>0.5)$ \\
\hline protein_2 & 0.403699 & no shedding events predicted (ShedP value $<0.5)$ \\
\hline
\end{tabular}

Fig. 4 Web interface for ShedP prediction. To predict the shedding events, the users can insert the protein sequence (FASTA format) of a queried protein in "Prediction" pages. In the prediction result pages, the ShedP prediction results will be revealed. The protein will be regarded as positive and predicted to be shed if the ShedP prediction value is greater than or equal to 0.5 , otherwise predicted as negative and nonshed 


\section{Additional file}

Additional file 1: Table S1. The details of the identified 401 shed membrane proteins including the protein UniProt ID and the PubMed ID for literature references. Table S2. The details of the shed membrane protein members in each group of function category. (PDF 303 kb)

\section{Acknowledgements}

We thank Dr. Hsuan-Cheng Huang at the Institute of Biomedical Informatics, National Yang Ming University, for support and inspiring discussions.

\section{Declarations}

This article has been published as part of BMC Bioinformatics Volume 18 Supplement 3, 2017. Selected articles from the 15th Asia Pacific Bioinformatics Conference (APBC 2017): bioinformatics. The full contents of the supplement are available online https:// bmcbioinformatics.biomedcentral.com/articles/supplements/volume-18 supplement-3.

\section{Funding}

This work and the publication cost of this manuscript was financially supported by the Ministry of Science and Technology, Taiwan under the contract number of MOST104-2221-E-010-009-MY2.

\section{Availability of data and materials}

The database is available at http://bal.ym.edu.tw/SheddomeDB/.

\section{Authors' contributions}

WST conceived the study, wrote the software, and wrote the paper. JHC wrote the software. KPW conceived the study and wrote the paper. All authors read and approved the final manuscript.

\section{Competing interests}

The authors declare that they have no competing interests.

\section{Consent for publication}

Not applicable.

\section{Ethics approval and consent to participate}

Not applicable.

\section{Author details}

${ }^{1}$ Institute of Biomedical Informatics, National Yang Ming University, Taipei 112, Taiwan. ${ }^{2}$ Bioinformatics Program, Taiwan International Graduate Program, Academia Sinica, Taipei 115, Taiwan. ${ }^{3}$ Department of Computer Science, National Taipei University of Education, Taipei 106, Taiwan.

Published: 14 March 2017

\section{References}

1. Makridakis M, Vlahou A. Secretome proteomics for discovery of cancer biomarkers. J Proteome. 2010;73(12):2291-305.

2. Damas JK, Gullestad L, Aukrust P. Cytokines as new treatment targets in chronic heart failure Curr Control Trials Cardiovasc Med. 2001:2(6):271-7.

3. Arribas J, Borroto A. Protein ectodomain shedding. Chem Rev. 2002; 102(12):4627-38

4. de Oca BP M. Ectdomain shedding and regulated intracellular proteolysis in the central nervous system. Cent Nerv Syst Agents Med Chem. 2010:10(4):337-59.

5. Hayashida K, Bartlett AH, Chen Y, Park PW. Molecular and cellular mechanisms of ectodomain shedding. Anat Rec (Hoboken). 2010; 293(6):925-37.

6. Arribas J, Massague J. Transforming growth factor-alpha and beta-amyloid precursor protein share a secretory mechanism. J Cell Biol. 1995;128(3):433-41.

7. Rawlings ND, Barrett AJ, Finn R. Twenty years of the MEROPS database of proteolytic enzymes, their substrates and inhibitors. Nucleic Acids Res. 2016; 44(D1):D343-350.

8. Igarashi Y, Heureux E, Doctor KS, Talwar P, Gramatikova S, Gramatikoff K Zhang Y, Blinov M, Ibragimova SS, Boyd S, et al. PMAP: databases for analyzing proteolytic events and pathways. Nucleic Acids Res. 2009; 37(Database issue):D611-618.
9. Prasad TS, Kandasamy K, Pandey A. Human protein reference database and human proteinpedia as discovery tools for systems biology. Methods Mol Biol. 2009;577:67-79.

10. Becker-Pauly $C$, Barre O, Schilling O, Auf dem Keller U, Ohler A, Broder C, Schutte A, Kappelhoff R, Stocker W, Overall CM. Proteomic analyses reveal an acidic prime side specificity for the astacin metalloprotease family reflected by physiological substrates. Mol Cell Proteomics. 2011;10(9):M111 009233.

11. Schilling O, Overall CM. Proteome-derived, database-searchable peptide libraries for identifying protease cleavage sites. Nat Biotechnol. 2008; 26(6):685-94.

12. Tien WS, Chen YT, Wu KP. SecretePipe: a screening pipeline for secreted proteins with competence to identify potential membrane-bound shed markers. J Proteome Res. 2013;12(3):1235-44.

13. UniProt Consortium. UniProt: a hub for protein information. Nucleic Acids Res. 2015:43(Database issue):D204-12

14. Cortes C, Vapnik V. Support vector network. Mach Learn. 1995:20:273-97.

15. Chou KC. Prediction of protein cellular attributes using pseudo-amino acid composition. Proteins. 2001;43(3):246-55.

16. Parr-Sturgess CA, Tinker CL, Hart CA, Brown MD, Clarke NW, Parkin ET. Copper modulates zinc metalloproteinase-dependent ectodomain shedding of key signaling and adhesion proteins and promotes the invasion of prostate cancer epithelial cells. Mol Cancer Res. 2012; 10(10):1282-93.

17. Tsaur I, Thurn K, Juengel E, Gust KM, Borgmann H, Mager R, Bartsch G, Oppermann E, Ackermann H, Nelson K, et al. sE-cadherin serves as a diagnostic and predictive parameter in prostate cancer patients. J Exp Clin Cancer Res. 2015;34:43.

18. Tsalikidis C, Papachristou F, Pitiakoudis M, Asimakopoulos B, Trypsianis G, Bolanaki E, Syrigos KN, Simopoulos C. Soluble E-cadherin as a diagnostic and prognostic marker in gastric carcinoma. Folia Med. 2013:55(3-4):26-32.

19. leguchi K, Tomita T, Omori T, Komatsu A, Deguchi A, Masuda J, Duffy SL, Coulthard MG, Boyd A, Maru Y. ADAM12-cleaved ephrin-A1 contributes to lung metastasis. Oncogene. 2014;33(17):2179-90.

20. Wang X, Zuo D, Chen Y, Li W, Liu R, He Y, Ren L, Zhou L, Deng T, Ying G, et al. Shed Syndecan-1 is involved in chemotherapy resistance via the EGFR pathway in colorectal cancer. Br J Cancer. 2014;111(10):1965-76.

21. Sung JY, Park SM, Lee CH, Um JW, Lee HJ, Kim J, Oh YJ, Lee ST, Paik SR, Chung KC. Proteolytic cleavage of extracellular secreted \{alpha\}-synuclein via matrix metalloproteinases. J Biol Chem. 2005;280(26):25216-24.

22. Haass C, Kaether C, Thinakaran G, Sisodia S. Trafficking and proteolytic processing of APP. Cold Spring Harb Perspect Med. 2012;2(5):a006270

23. Pruessmeyer J, Ludwig A. The good, the bad and the ugly substrates for ADAM10 and ADAM17 in brain pathology, inflammation and cancer. Semin Cell Dev Biol. 2009;20(2):164-74.

24. Fassold A, Falk W, Anders S, Hirsch T, Mirsky VM, Straub RH. Soluble neuropilin-2, a nerve repellent receptor, is increased in rheumatoid arthritis synovium and aggravates sympathetic fiber repulsion and arthritis. Arthritis Rheum. 2009;60(10):2892-901.

25. Wu H, Zhou Q, Xie J, Li GN, Chen QH, Kang LN, Xu B. Syndecan-4 shedding is involved in the oxidative stress and inflammatory responses in left atrial tissue with valvular atrial fibrillation. Int J Clin Exp Pathol. 2015:8(6):6387-96.

26. Clayton KL, Douglas-Vail MB, Nur-ur Rahman AK, Medcalf KE, Xie IY, Chew GM, Tandon R, Lanteri MC, Norris PJ, Deeks SG, et al. Soluble T cell immunoglobulin mucin domain 3 is shed from CD8+ T cells by the sheddase ADAM10, is increased in plasma during untreated HIV infection, and correlates with HIV disease progression. J Virol. 2015; 89(7):3723-36.

27. Yoneshige A, Hagiyama M, Inoue T, Mimae T, Kato T, Okada M, Enoki E, Ito A. Increased ectodomain shedding of cell adhesion molecule 1 as a cause of type II alveolar epithelial cell apoptosis in patients with idiopathic interstitial pneumonia. Respir Res. 2015;16:90.

28. Inoue T, Hagiyama M, Yoneshige A, Kato T, Enoki E, Maenishi O, Chikugo T, Kimura M, Satou T, Ito A. Increased ectodomain shedding of cell adhesion molecule 1 from pancreatic islets in type 2 diabetic pancreata: correlation with hemoglobin A1c levels. PLoS One. 2014;9(6):e100988.

29. Fabre-Lafay S, Garrido-Urbani S, Reymond N, Goncalves A, Dubreuil P, Lopez M. Nectin-4, a new serological breast cancer marker, is a substrate for tumor necrosis factor-alpha-converting enzyme (TACE)/ADAM-17. J Biol Chem. 2005;280(20):19543-50. 
30. Elomaa O, Pulkkinen K, Hannelius U, Mikkola M, Saarialho-Kere U, Kere J. Ectodysplasin is released by proteolytic shedding and binds to the EDAR protein. Hum Mol Genet. 2001;10(9):953-62.

31. Wong KK, Brenneman F, Chesney A, Spaner DE, Gorczynski RM. Soluble CD200 is critical to engraft chronic lymphocytic leukemia cells in immunocompromised mice. Cancer Res. 2012;72(19):4931-43.

32. Bartolome RA, Pelaez-Garcia A, Gomez I, Torres S, Fernandez-Acenero MJ, Escudero-Paniagua B, Imbaud JI, Casal JI. An RGD motif present in cadherin 17 induces integrin activation and tumor growth. J Biol Chem. 2014;289(50):34801-14.

33. Tsukamoto S, Takeuchi M, Kawaguchi T, Togasaki E, Yamazaki A, Sugita Y, Muto T, Sakai S, Takeda Y, Ohwada C, et al. Tetraspanin CD9 modulates ADAM17mediated shedding of LR11 in leukocytes. Exp Mol Med. 2014;46:e89.

34. Ogita M, Miyauchi K, Jiang M, Kasai T, Tsuboi S, Naito R, Konishi H, Dohi T, Yokoyama T, Okazaki S, et al. Circulating soluble LR11, a novel marker of smooth muscle cell proliferation, is enhanced after coronary stenting in response to vascular injury. Atherosclerosis. 2014;237(1):374-8.

35. Takahashi M, Bujo H, Jiang M, Noike H, Saito Y, Shirai K. Enhanced circulating soluble LR11 in patients with coronary organic stenosis. Atherosclerosis. 2010;210(2):581-4.

36. Takahashi M, Bujo H, Shiba T, Jiang M, Maeno T, Shirai K. Enhanced circulating soluble LR11 in patients with diabetic retinopathy. Am J Ophthalmol. 2012;154(1):187-92.

37. Ma YJ, Hein E, Munthe-Fog L, Skjoedt MO, Bayarri-Olmos R, Romani L, Garred P. Soluble collectin-12 (CL-12) is a pattern recognition molecule initiating complement activation via the alternative pathway. J Immunol. 2015;195(7):3365-73

38. Mendelson K, Swendeman S, Saftig P, Blobel CP. Stimulation of plateletderived growth factor receptor beta (PDGFRbeta) activates ADAM17 and promotes metalloproteinase-dependent cross-talk between the PDGFRbeta and epidermal growth factor receptor (EGFR) signaling pathways. J Biol Chem. 2010;285(32):25024-32.

39. Sagare AP, Sweeney MD, Makshanoff J, Zlokovic BV. Shedding of soluble platelet-derived growth factor receptor-beta from human brain pericytes. Neurosci Lett. 2015;607:97-101.

40. Moratti E, Vezzalini M, Tomasello L, Giavarina D, Sorio C. Identification of protein tyrosine phosphatase receptor gamma extracellular domain (sPTPRG) as a natural soluble protein in plasma. PLoS One. 2015;10(3): e0119110.

41. Garton KJ, Gough PJ, Raines EW. Emerging roles for ectodomain shedding in the regulation of inflammatory responses. J Leukoc Biol. 2006;79(6):1105-16.

42. Pupovac A, Foster CM, Sluyter R. Human P2X7 receptor activation induces the rapid shedding of CXCL16. Biochem Biophys Res Commun. 2013;432(4):626-31.

43. Hansen HP, Dietrich S, Kisseleva T, Mokros T, Mentlein R, Lange HH, Murphy G, Lemke H. CD30 shedding from Karpas 299 lymphoma cells is mediated by TNF-alpha-converting enzyme. J Immunol. 2000;165(12):6703-9.

44. Li N, Wang Y, Forbes K, Vignali KM, Heale BS, Saftig P, Hartmann D, Black RA, Rossi JJ, Blobel CP, et al. Metalloproteases regulate T-cell proliferation and effector function via LAG-3. EMBO J. 2007;26(2):494-504.

45. Masilamani M, Kassahn D, Mikkat S, Glocker MO, Illges H. B cell activation leads to shedding of complement receptor type II (CR2/CD21). Eur J Immunol. 2003:33(9):2391-7.

46. Gatto G, Morales D, Kania A, Klein R. EphA4 receptor shedding regulates spinal motor axon guidance. Curr Biol. 2014:24(20):2355-65.

47. Okamura Y, Kohmura E, Yamashita T. TACE cleaves neogenin to desensitize cortical neurons to the repulsive guidance molecule. Neurosci Res. 2011;71(1):63-70.

48. Hubschmann MV, Skladchikova G, Bock E, Berezin V. Neural cell adhesion molecule function is regulated by metalloproteinase-mediated ectodomain release. J Neurosci Res. 2005;80(6):826-37.

49. Walmsley AR, McCombie G, Neumann U, Marcellin D, Hillenbrand R, Mir AK, Frentzel S. Zinc metalloproteinase-mediated cleavage of the human Nogo66 receptor. J Cell Sci. 2004;117(Pt 19):4591-602.

50. Ahmed Z, Mazibrada G, Seabright RJ, Dent RG, Berry M, Logan A. TACEinduced cleavage of $\mathrm{NgR}$ and p75NTR in dorsal root ganglion cultures disinhibits outgrowth and promotes branching of neurites in the presence of inhibitory CNS myelin. FASEB J. 2006;20(11):1939-41.

51. Rabquer BJ, Amin MA, Teegala N, Shaheen MK, Tsou PS, Ruth JH, Lesch CA, Imhof BA, Koch AE. Junctional adhesion molecule-C is a soluble mediator of angiogenesis. J Immunol. 2010;185(3):1777-85.
52. Noy PJ, Swain RK, Khan K, Lodhia P, Bicknell R. Sprouting angiogenesis is regulated by shedding of the C-type lectin family 14, member A (CLEC14A) ectodomain, catalyzed by rhomboid-like 2 protein (RHBDL2). FASEB J. 2016; 30:2311-2323.

53. Liang X, Russell SR, Estelle S, Jones LH, Cho S, Kahn ML, Berndt MC, Bunting ST, Ware J, Li R. Specific inhibition of ectodomain shedding of glycoprotein Ibalpha by targeting its juxtamembrane shedding cleavage site. J Thromb Haemost. 2013;11(12):2155-62.

54. Sahin U, Weskamp G, Kelly K, Zhou HM, Higashiyama S, Peschon J, Hartmann D, Saftig P, Blobel CP. Distinct roles for ADAM10 and ADAM17 in ectodomain shedding of six EGFR ligands. J Cell Biol. 2004;164(5):769-79.

55. Sunnarborg SW, Hinkle CL, Stevenson M, Russell WE, Raska CS, Peschon JJ, Castner BJ, Gerhart MJ, Paxton RJ, Black RA, et al. Tumor necrosis factoralpha converting enzyme (TACE) regulates epidermal growth factor receptor ligand availability. J Biol Chem. 2002;277(15):12838-45.

56. Weskamp G, Schlondorff J, Lum L, Becherer JD, Kim TW, Saftig P, Hartmann D, Murphy G, Blobel CP. Evidence for a critical role of the tumor necrosis factor alpha convertase (TACE) in ectodomain shedding of the p75 neurotrophin receptor (p75NTR). J Biol Chem. 2004:279(6):4241-9.

57. Srinivasan B, Wang Z, Brun-Zinkernagel AM, Collier RJ, Black RA, Frank SJ, Barker PA, Roque RS. Photic injury promotes cleavage of p75NTR by TACE and nuclear trafficking of the p75 intracellular domain. Mol Cell Neurosci. 2007;36(4):449-61.

58. Ohlig S, Pickhinke U, Sirko S, Bandari S, Hoffmann D, Dreier R, Farshi P, Gotz M, Grobe K. An emerging role of Sonic hedgehog shedding as a modulator of heparan sulfate interactions. J Biol Chem. 2012;287(52):43708-19.

59. Maetzel D, Denzel S, Mack B, Canis M, Went P, Benk M, Kieu C, Papior P, Baeuerle PA, Munz M, et al. Nuclear signalling by tumour-associated antigen EpCAM. Nat Cell Biol. 2009;11(2):162-71.

60. Nava P, Kamekura R, Nusrat A. Cleavage of transmembrane junction proteins and their role in regulating epithelial homeostasis. Tissue barriers. 2013:1(2):e24783.

61. Wang Y, Sul HS. Ectodomain shedding of preadipocyte factor 1 (Pref-1) by tumor necrosis factor alpha converting enzyme (TACE) and inhibition of adipocyte differentiation. Mol Cell Biol. 2006;26(14):5421-35.

62. Fenech M, Gavrilovic J, Turner J. Effect of tissue inhibitor of metalloproteinases 3 on DLK1 shedding in cultured human pre-adipocytes and implications for adipose tissue remodelling. Lancet. 2015;385 Suppl 1:S35.

63. Kummer MP, Maruyama H, Huelsmann C, Baches S, Weggen S, Koo EH. Formation of Pmel17 amyloid is regulated by juxtamembrane metalloproteinase cleavage, and the resulting C-terminal fragment is a substrate for gamma-secretase. J Biol Chem. 2009;284(4):2296-306.

64. Esterhazy D, Akpinar P, Stoffel M. Tmem27 dimerization, deglycosylation, plasma membrane depletion, and the extracellular Phe-Phe motif are negative regulators of cleavage by Bace2. Biol Chem. 2012;393(6):473-84.

65. Akpinar P, Kuwajima S, Krutzfeldt J, Stoffel M. Tmem27: a cleaved and shed plasma membrane protein that stimulates pancreatic beta cell proliferation. Cell Metab. 2005;2(6):385-97.

66. Fukuoka S, Kobayashi K. Analysis of the C-terminal structure of urinary TammHorsfall protein reveals that the release of the glycosyl phosphatidylinositolanchored counterpart from the kidney occurs by phenylalanine-specific proteolysis. Biochem Biophys Res Commun. 2001;289(5):1044-8.

67. Sadhukhan R, Santhamma KR, Reddy P, Peschon JJ, Black RA, Sen I. Unaltered cleavage and secretion of angiotensin-converting enzyme in tumor necrosis factor-alpha-converting enzyme-deficient mice. J Biol Chem. 1999;274(15):10511-6.

68. Elwood PC, Deutsch JC, Kolhouse JF. The conversion of the human membrane-associated folate binding protein (folate receptor) to the soluble folate binding protein by a membrane-associated metalloprotease. J Biol Chem. 1991:266(4):2346-53.

69. Kamekura R, Nava P, Feng M, Quiros M, Nishio H, Weber DA, Parkos CA, Nusrat A. Inflammation-induced desmoglein-2 ectodomain shedding compromises the mucosal barrier. Mol Biol Cell. 2015;26(18):3165-77.

70. Chen CD, Tung TY, Liang J, Zeldich E, Tucker Zhou TB, Turk BE, Abraham CR Identification of cleavage sites leading to the shed form of the anti-aging protein klotho. Biochemistry. 2014:53(34):5579-87.

71. Bloch L, Sineshchekova O, Reichenbach D, Reiss K, Saftig P, Kuro-o M, Kaether C. Klotho is a substrate for alpha-, beta- and gamma-secretase. FEBS Lett. 2009;583(19):3221-4.

72. Stutzer I, Selevsek N, Esterhazy D, Schmidt A, Aebersold R, Stoffel M. Systematic proteomic analysis identifies beta-site amyloid precursor protein 
cleaving enzyme 2 and 1 (BACE2 and BACE1) substrates in pancreatic betacells. J Biol Chem. 2013;288(15):10536-47.

73. Fong KP, Barry C, Tran AN, Traxler EA, Wannemacher KM, Tang HY, Speicher KD, Blair IA, Speicher DW, Grosser T, et al. Deciphering the human platelet sheddome. Blood. 2011;117(1):e15-26.

74. Kuhn PH, Koroniak K, Hogl S, Colombo A, Zeitschel U, Willem M, Volbracht C, Schepers U, Imhof A, Hoffmeister A, et al. Secretome protein enrichment identifies physiological BACE1 protease substrates in neurons. EMBO J. 2012; 31(14):3157-68.

75. Clark EB, Jovov B, Rooj AK, Fuller CM, Benos DJ. Proteolytic cleavage of human acid-sensing ion channel 1 by the serine protease matriptase. J Biol Chem. 2010;285(35):27130-43.

76. Hakalahti AE, Khan H, Vierimaa MM, Pekkala EH, Lackman JJ, Ulvila J, Kerkela $R$, Petaja-Repo UE. beta-Adrenergic agonists mediate enhancement of beta1-adrenergic receptor $\mathrm{N}$-terminal cleavage and stabilization in vivo and in vitro. Mol Pharmacol. 2013;83(1):129-41.

77. Lammers G, Jamieson JC. Studies on the effect of lysosomotropic agents on the release of Gal beta 1-4GICNAc alpha-2,6-sialytransferase from rat liver slices during the acute-phase response. Biochem J. 1989;261(2):389-93.

78. Willemsen LE, Hoetjes JP, van Deventer SJ, van Tol EA. Abrogation of IFNgamma mediated epithelial barrier disruption by serine protease inhibition. Clin Exp Immunol. 2005;142(2):275-84.

79. Cui D, Arima M, Takubo K, Kimura T, Horiuchi K, Minagawa T, Matsuda S, Ikeda E. ADAM12 and ADAM17 are essential molecules for hypoxia-induced impairment of neural vascular barrier function. Sci Rep. 2015;5:12796.

80. Veit G, Zimina EP, Franzke CW, Kutsch S, Siebolds U, Gordon MK, BrucknerTuderman L, Koch M. Shedding of collagen XXIII is mediated by furin and depends on the plasma membrane microenvironment. J Biol Chem. 2007; 282(37):27424-35.

81. Banyard J, Bao L, Zetter BR. Type XXIII collagen, a new transmembrane collagen identified in metastatic tumor cells. J Biol Chem. 2003;278(23): 20989-94.

82. Kuruppu S, Reeve S, Ian Smith A. Characterisation of endothelin converting enzyme-1 shedding from endothelial cells. FEBS Lett. 2007;581(23):4501-6.

83. Bruney L, Conley KC, Moss NM, Liu Y, Stack MS. Membrane-type I matrix metalloproteinase-dependent ectodomain shedding of mucin16/CA-125 on ovarian cancer cells modulates adhesion and invasion of peritoneal mesothelium. Biol Chem. 2014;395(10):1221-31.

84. Sanz R, Ferraro GB, Fournier AE. IgLON cell adhesion molecules are shed from the cell surface of cortical neurons to promote neuronal growth. J Biol Chem. 2015;290(7):4330-42.

85. Ahn BJ, Le H, Shin MW, Bae SJ, Lee EJ, Wee HJ, Cha JH, Park JH, Lee HS, Lee $\mathrm{HJ}$, et al. The N-terminal ectodomain of Ninjurin1 liberated by MMP9 has chemotactic activity. Biochem Biophys Res Commun. 2012;428(4):438-44.

86. Lee HS, Park BM, Cho Y, Kim S, Kim C, Kim MG, Park D. Shedding of epithin/PRSS14 is induced by TGF-beta and mediated by tumor necrosis factor-alpha converting enzyme. Biochem Biophys Res Commun. 2014;452(4):1084-90.

87. Kim SB, Lee D, Jeong JW, Kim C, Park D, Kim MG. Soluble epithin/PRSS14 secreted from cancer cells contains active angiogenic potential. Mol Cells. 2010;29(6):617-23.

88. Sonoda K, Kato K. A disintegrin and metalloproteinase 9 is involved in ectodomain shedding of receptor-binding cancer antigen expressed on SiSo cells. Biomed Res Int. 2014;2014:482396.

89. Pagani A, Vieillevoye M, Nai A, Rausa M, Ladli M, Lacombe C, Mayeux P, Verdier F, Camaschella C, Silvestri L. Regulation of cell surface transferrin receptor-2 by iron-dependent cleavage and release of a soluble form. Haematologica. 2015;100(4):458-65.

90. Jiang J, Yang J, Feng P, Zuo B, Dong N, Wu Q, He Y. N-glycosylation is required for matriptase-2 autoactivation and ectodomain shedding. J Biol Chem. 2014;289(28):19500-7.

91. Salih HR, Schmetzer HM, Burke C, Starling GC, Dunn R, Pelka-Fleischer R, Nuessler V, Kiener PA. Soluble CD137 (4-1BB) ligand is released following leukocyte activation and is found in sera of patients with hematological malignancies. J Immunol. 2001;167(7):4059-66.

92. Hoffmann FS, Kuhn PH, Laurent SA, Hauck SM, Berer K, Wendlinger SA Krumbholz M, Khademi M, Olsson T, Dreyling M, et al. The immunoregulator soluble TACl is released by ADAM10 and reflects $B$ cell activation in autoimmunity. J Immunol. 2015;194(2):542-52.

93. Tanikawa C, Ri C, Kumar V, Nakamura Y, Matsuda K. Crosstalk of EDA-A2 XEDAR in the p53 signaling pathway. Mol Cancer Res. 2010;8(6):855-63.
94. Klenk C, Schulz S, Calebiro D, Lohse MJ. Agonist-regulated cleavage of the extracellular domain of parathyroid hormone receptor type 1. J Biol Chem. 2010;285(12):8665-74.

95. Browne K, Wang W, Liu RQ, Piva M, O'Connor TP. Transmembrane semaphorin5B is proteolytically processed into a repulsive neural guidance cue. J Neurochem. 2012;123(1):135-46.

96. Kojro E, Fahrenholz F. Ligand-induced cleavage of the V2 vasopressin receptor by a plasma membrane metalloproteinase. J Biol Chem. 1995; 270(12):6476-81.

97. Hicks D, John D, Makova NZ, Henderson Z, Nalivaeva NN, Turner AJ. Membrane targeting, shedding and protein interactions of brain acetylcholinesterase. J Neurochem. 2011;116(5):742-6.

98. Zhang L, Bukulin M, Kojro E, Roth A, Metz W, Fahrenholz F, Nawroth PP, Bierhaus A, Postina R. Receptor for advanced glycation end products is subjected to protein ectodomain shedding by metalloproteinases. J Biol Chem. 2008;283(51):35507-16.

99. van Hensbergen Y, Broxterman HJ, Hanemaaijer R, Jorna AS, van Lent NA, Verheul HM, Pinedo HM, Hoekman K. Soluble aminopeptidase N/CD13 in malignant and nonmalignant effusions and intratumoral fluid. Clin Cancer Res. 2002;8(12):3747-54.

100. Causin C, Waheed A, Braulke T, Junghans U, Maly P, Humbel RE, von Figura K. Mannose 6-phosphate/insulin-like growth factor II-binding proteins in human serum and urine. Their relation to the mannose 6-phosphate/ insulin-like growth factor II receptor. Biochem J. 1988;252(3):795-9.

101. Tejeda GS, Ayuso-Dolado S, Arbeteta R, Esteban-Ortega GM, Vidaurre OG, Diaz-Guerra M. Brain ischaemia induces shedding of a BDNF-scavenger ectodomain from TrkB receptors by excitotoxicity activation of metalloproteinases and gamma-secretases. J Pathol. 2016;238(5):627-40.

102. Strous GJ. Golgi and secreted galactosyltransferase. CRC Crit Rev Biochem. 1986;21(2):119-51.

103. Schaub BE, Berger B, Berger EG, Rohrer J. Transition of galactosyltransferase 1 from trans-Golgi cisterna to the trans-Golgi network is signal mediated. Mol Biol Cell. 2006;17(12):5153-62.

104. Cork SM, Kaur B, Devi NS, Cooper L, Saltz JH, Sandberg EM, Kaluz S, Van Meir EG. A proprotein convertase/MMP-14 proteolytic cascade releases a novel $40 \mathrm{kDa}$ vasculostatin from tumor suppressor BAl1. Oncogene. 2012;31(50):5144-52.

105. Rattner A, Chen J, Nathans J. Proteolytic shedding of the extracellular domain of photoreceptor cadherin. Implications for outer segment assembly. J Biol Chem. 2004;279(40):42202-10.

106. Albitar M, Do KA, Johnson MM, Giles FJ, Jilani I, O'Brien S, Cortes J, Thomas D, Rassenti LZ, Kipps TJ, et al. Free circulating soluble CD52 as a tumor marker in chronic lymphocytic leukemia and its implication in therapy with anti-CD52 antibodies. Cancer. 2004;101(5):999-1008.

107. Markel G, Achdout H, Katz G, Ling KL, Salio M, Gruda R, Gazit R, Mizrahi S, Hanna J, Gonen-Gross T, et al. Biological function of the soluble CEACAM1 protein and implications in TAP2-deficient patients. Eur J Immunol. 2004; 34(8):2138-48.

108. Komada Y, Zhang SL, Zhou YW, Shibata T, Azuma E, Sakurai M. Shedding of CD9 antigen by bone marrow cells from patients with acute lymphoblastic leukaemia. Br J Haematol. 1992;81 (4):526-9.

109. Komada Y, Sakurai M. Shedding of CD9 antigen in acute lymphoblastic leukemia. Leuk Lymphoma. 1994;12(5-6):365-72.

110. Giustiniani J, Marie-Cardine A, Bensussan A. A soluble form of the MHC class I-specific CD160 receptor is released from human activated NK lymphocytes and inhibits cell-mediated cytotoxicity. J Immunol. 2007;178(3):1293-300.

111. Elishmereni M, Levi-Schaffer F. CD48: A co-stimulatory receptor of immunity. Int J Biochem Cell Biol. 2011;43(1):25-8.

112. Smith GM, Biggs J, Norris B, Anderson-Stewart P, Ward R. Detection of a soluble form of the leukocyte surface antigen CD48 in plasma and its elevation in patients with lymphoid leukemias and arthritis. J Clin Immunol. 1997;17(6):502-9.

113. Boles KS, Stepp SE, Bennett M, Kumar V, Mathew PA. 2 B4 (CD244) and CS1: novel members of the CD2 subset of the immunoglobulin superfamily molecules expressed on natural killer cells and other leukocytes. Immunol Rev. 2001;181:234-49.

114. Wang T, Ward Y, Tian L, Lake R, Guedez L, Stetler-Stevenson WG, Kelly K. CD97, an adhesion receptor on inflammatory cells, stimulates angiogenesis through binding integrin counterreceptors on endothelial cells. Blood. 2005: 105(7):2836-44.

115. Karpus ON, Veninga H, Hoek RM, Flierman D, van Buul JD, Vandenakker CC, vanBavel E, Medof ME, van Lier RA, Reedquist KA, et al. Shear stress- 
dependent downregulation of the adhesion-G protein-coupled receptor CD97 on circulating leukocytes upon contact with its ligand CD55. J Immunol. 2013;190(7):3740-8.

116. Bardin N, Blot-Chabaud M, Despoix N, Kebir A, Harhouri K, Arsanto JP, Espinosa L, Perrin P, Robert S, Vely F, et al. CD146 and its soluble form regulate monocyte transendothelial migration. Arterioscler Thromb Vasc Biol. 2009;29(5):746-53.

117. Davis S, Aldrich TH, Ip NY, Stahl N, Scherer S, Farruggella T, DiStefano PS, Curtis R, Panayotatos N, Gascan H, et al. Released form of CNTF receptor alpha component as a soluble mediator of CNTF responses. Science. 1993; 259(5102):1736-9.

118. Bohlson SS, Silva R, Fonseca MI, Tenner AJ. CD93 is rapidly shed from the surface of human myeloid cells and the soluble form is detected in human plasma. J Immunol. 2005;175(2):1239-47.

119. Danielsson C, Pascual M, French L, Steiger G, Schifferli JA. Soluble complement receptor type 1 (CD35) is released from leukocytes by surface cleavage. Eur J Immunol. 1994;24(11):2725-31.

120. Yamaguchi N, Plant C, Biancone L, Bachovchin W, McCluskey R, Andres G. In vivo modulation of CD26 (dipeptidyl peptidase IV) in the mouse: effects of polyreactive and monoreactive antibodies. Transplantation. 1996;62(7):973-85.

121. Rohrborn D, Eckel J, Sell H. Shedding of dipeptidyl peptidase 4 is mediated by metalloproteases and up-regulated by hypoxia in human adipocytes and smooth muscle cells. FEBS Lett. 2014;588(21):3870-7.

122. Schramm RD, Li S, Harris BS, Rounds RP, Burgess RW, Ytreberg FM, Fuerst PG. A novel mouse Dscam mutation inhibits localization and shedding of DSCAM. PLoS One. 2012;7(12):e52652.

123. Velayos-Baeza A, Levecque C, Kobayashi K, Holloway ZG, Monaco AP. The dyslexia-associated KIAA0319 protein undergoes proteolytic processing with \{gamma\}-secretase-independent intramembrane cleavage. J Biol Chem. 2010;285(51):40148-62.

124. Hattori M, Osterfield M, Flanagan JG. Regulated cleavage of a contactmediated axon repellent. Science. 2000;289(5483):1360-5.

125. Janes PW, Saha N, Barton WA, Kolev MV, Wimmer-Kleikamp SH, Nievergall E, Blobel CP, Himanen JP, Lackmann M, Nikolov DB. Adam meets Eph: an ADAM substrate recognition module acts as a molecular switch for ephrin cleavage in trans. Cell. 2005;123(2):291-304.

126. Sahin U, Blobel CP. Ectodomain shedding of the EGF-receptor ligand epigen is mediated by ADAM17. FEBS Lett. 2007;581(1):41-4.

127. Peduto L, Reuter VE, Shaffer DR, Scher HI, Blobel CP. Critical function for ADAM9 in mouse prostate cancer. Cancer Res. 2005:65(20):9312-9.

128. Degnin CR, Laederich MB, Horton WA. Ligand activation leads to regulated intramembrane proteolysis of fibroblast growth factor receptor 3. Mol Biol Cell. 2011;22(20):3861-73.

129. Hiesberger T, Gourley E, Erickson A, Koulen P, Ward CJ, Masyuk TV, Larusso NF, Harris PC, Igarashi P. Proteolytic cleavage and nuclear translocation of fibrocystin is regulated by intracellular Ca2+ and activation of protein kinase C. J Biol Chem. 2006;281(45):34357-64.

130. Kaimori JY, Nagasawa Y, Menezes LF, Garcia-Gonzalez MA, Deng J, Imai E, Onuchic LF, Guay-Woodford LM, Germino GG. Polyductin undergoes notchlike processing and regulated release from primary cilia. Hum Mol Genet. 2007:16(8):942-56.

131. Strand S, Vollmer P, van den Abeelen L, Gottfried D, Alla V, Heid H, Kuball J, Theobald M, Galle PR, Strand D. Cleavage of CD95 by matrix metalloproteinase-7 induces apoptosis resistance in tumour cells. Oncogene. 2004:23(20):3732-6.

132. Hemming ML, Elias JE, Gygi SP, Selkoe DJ. Identification of beta-secretase (BACE1) substrates using quantitative proteomics. PLoS One. 2009;4(12):e8477.

133. Vallon M, Essler M. Proteolytically processed soluble tumor endothelial marker (TEM) 5 mediates endothelial cell survival during angiogenesis by linking integrin alpha(v)beta3 to glycosaminoglycans. J Biol Chem. 2006; 281(45):34179-88.

134. Maxson JE, Chen J, Enns CA, Zhang AS. Matriptase-2- and proprotein convertase-cleaved forms of hemojuvelin have different roles in the downregulation of hepcidin expression. J Biol Chem. 2010;285(50):39021-8.

135. Guo L, Takino T, Endo Y, Domoto T, Sato H. Shedding of kidney injury molecule-1 by membrane-type 1 matrix metalloproteinase. J Biochem. 2012 152(5):425-32.

136. Schweigert O, Dewitz C, Moller-Hackbarth K, Trad A, Garbers C, Rose-John S, Scheller J. Soluble T cell immunoglobulin and mucin domain (TIM)-1 and -4 generated by A Disintegrin And Metalloprotease (ADAM)-10 and -17 bind to phosphatidylserine. Biochim Biophys Acta. 2014;1843(2):275-87.
137. Diaz-Rodriguez E, Montero JC, Esparis-Ogando A, Yuste L, Pandiella A. Extracellular signal-regulated kinase phosphorylates tumor necrosis factor alpha-converting enzyme at threonine 735 : a potential role in regulated shedding. Mol Biol Cell. 2002;13(6):2031-44.

138. Derre L, Corvaisier M, Charreau B, Moreau A, Godefroy E, Moreau-Aubry A, Jotereau F, Gervois N. Expression and release of HLA-E by melanoma cells and melanocytes: potential impact on the response of cytotoxic effector cells. J Immunol. 2006;177(5):3100-7.

139. Park GM, Lee S, Park B, Kim E, Shin J, Cho K, Ahn K. Soluble HLA-G generated by proteolytic shedding inhibits NK-mediated cell lysis. Biochem Biophys Res Commun. 2004;313(3):606-11.

140. Peng M, Guo S, Yin N, Xue J, Shen L, Zhao Q, Zhang W. Ectodomain shedding of Fcalpha receptor is mediated by ADAM10 and ADAM17. Immunology. 2010;130(1):83-91.

141. Sato H, Azuma Y, Higai K, Matsumoto K. Altered expression of glycoproteins on the cell surface of Jurkat cells during etoposide-induced apoptosis: shedding and intracellular translocation of glycoproteins. Biochim Biophys Acta. 2009;1790(10):1198-205.

142. Pino-Otin MR, Vinas $O$, de la Fuente MA, Juan M, Font J, Torradeflot $M$, Pallares L, Lozano F, Alberola-lla J, Martorell J, et al. Existence of a soluble form of CD50 (intercellular adhesion molecule-3) produced upon human lymphocyte activation. Present in normal human serum and levels are increased in the serum of systemic lupus erythematosus patients. J mmunol. 1995;154(6):3015-24.

143. Findley CM, Cudmore MJ, Ahmed A, Kontos CD. VEGF induces Tie2 shedding via a phosphoinositide 3-kinase/Akt dependent pathway to modulate Tie2 signaling. Arterioscler Thromb Vasc Biol. 2007;27(12):2619-26.

144. Vannier E, Kaser A, Atkins MB, Fantuzzi G, Dinarello CA, Mier JW, Tilg H. Elevated circulating levels of soluble interleukin-1 receptor type II during interleukin-2 immunotherapy. Eur Cytokine Netw. 1999;10(1):37-42.

145. Lokau J, Nitz R, Agthe M, Monhasery N, Aparicio-Siegmund S, Schumacher N, Wolf J, Moller-Hackbarth K, Waetzig GH, Grotzinger J, et al. Proteolytic cleavage governs interleukin-11 trans-signaling. Cell Rep. 2016;14(7):1761-73.

146. Matsumura M, Inoue H, Matsumoto T, Nakano T, Fukuyama S, Matsumoto K, Takayama K, Saito M, Kawakami K, Nakanishi Y. Endogenous metalloprotease solubilizes IL-13 receptor alpha2 in airway epithelial cells. Biochem Biophys Res Commun. 2007;360(2):464-9.

147. Chen W, Tabata Y, Gibson AM, Daines MO, Warrier MR, Wills-Karp M, Hershey GK. Matrix metalloproteinase 8 contributes to solubilization of IL-13 receptor alpha2 in vivo. J Allergy Clin Immunol. 2008;122(3):625-32.

148. Montes de Oca P, Malarde V, Proust R, Dautry-Varsat A, Gesbert F Ectodomain shedding of interleukin-2 receptor beta and generation of an intracellular functional fragment. J Biol Chem. 2010;285(29):22050-8.

149. Franke M, Schroder J, Monhasery N, Ackfeld T, Hummel TM, Rabe B, Garbers C, Becker-Pauly C, Floss DM, Scheller J. Human and murine interleukin 23 receptors are novel substrates for a disintegrin and metalloproteases ADAM10 and ADAM17. J Biol Chem. 2016;291(20):10551-61.

150. Jung T, Schrader N, Hellwig M, Enssle KH, Neumann C. Soluble human interleukin-4 receptor is produced by activated T cells under the control of metalloproteinases. Int Arch Allergy Immunol. 1999;1 19(1):23-30.

151. Liu LY, Sedgwick JB, Bates ME, Vrtis RF, Gern JE, Kita H, Jarjour NN, Busse WW, Kelly EA. Decreased expression of membrane IL-5 receptor alpha on human eosinophils: II. IL-5 down-modulates its receptor via a proteinasemediated process. J Immunol. 2002;169(11):6459-66.

152. Narazaki M, Yasukawa $K$, Saito T, Ohsugi Y, Fukui $H$, Koishihara $Y$, Yancopoulos GD, Taga T, Kishimoto T. Soluble forms of the interleukin-6 signal-transducing receptor component gp130 in human serum possessing a potential to inhibit signals through membrane-anchored gp130. Blood. 1993:82(4):1120-6.

153. Vranjkovic A, Crawley AM, Gee K, Kumar A, Angel JB. IL-7 decreases IL-7 receptor alpha (CD127) expression and induces the shedding of CD127 by human CD8+ T cells. Int Immunol. 2007;19(12):1329-39.

154. Yesildag B, Bock T, Herrmanns K, Wollscheid B, Stoffel M. Kin of IRRE-like protein 2 is a phosphorylated glycoprotein that regulates basal insulin secretion. J Biol Chem. 2015:290(43):25891-906.

155. Maamra M, Bidlingmaier M, Postel-Vinay MC, Wu Z, Strasburger CJ, Ross RJ. Generation of human soluble leptin receptor by proteolytic cleavage of membrane-anchored receptors. Endocrinology. 2001;142(10):4389-93.

156. Yamagishi S, Hampel F, Hata K, Del Toro D, Schwark M, Kvachnina E, Bastmeyer M, Yamashita T, Tarabykin V, Klein R, et al. FLRT2 and FLRT3 
act as repulsive guidance cues for Unc5-positive neurons. EMBO J. 2011:30(14):2920-33.

157. Lee H, Lee EJ, Song YS, Kim E. Long-term depression-inducing stimuli promote cleavage of the synaptic adhesion molecule NGL-3 through NMDA receptors, matrix metalloproteinases and presenilin/gamma-secretase. Philos Trans R Soc Lond Ser B Biol Sci. 2014;369(1633):20130158.

158. Yi W, Holmlund C, Nilsson J, Inui S, Lei T, Itami S, Henriksson R, Hedman H. Paracrine regulation of growth factor signaling by shed leucine-rich repeats and immunoglobulin-like domains 1. Exp Cell Res. 2011;317(4):504-12.

159. Xiao Q, Tan Y, Guo Y, Yang H, Mao F, Xie R, Wang B, Lei T, Guo D. Soluble $L R I G 2$ ectodomain is released from glioblastoma cells and promotes the proliferation and inhibits the apoptosis of glioblastoma cells in vitro and in vivo in a similar manner to the full-length LRIG2. PLoS One. 2014;9(10): e111419.

160. Astier A, de la Salle H, de la Salle C, Bieber T, Esposito-Farese ME, Freund M, Cazenave JP, Fridman WH, Teillaud JL, Hanau D. Human epidermal Langerhans cells secrete a soluble receptor for lgG (Fc gamma RII/CD32) that inhibits the binding of immune complexes to Fc gamma R+ cells. J Immunol. 1994;152(1):201-12.

161. Romee R, Foley B, Lenvik T, Wang Y, Zhang B, Ankarlo D, Luo X, Cooley S, Verneris $M$, Walcheck $B$, et al. NK cell CD16 surface expression and function is regulated by a disintegrin and metalloprotease-17 (ADAM17). Blood. 2013; 121(18):3599-608.

162. Wang Y, Wu J, Newton R, Bahaie NS, Long C, Walcheck B. ADAM17 cleaves CD16b (FcgammaRIIIb) in human neutrophils. Biochim Biophys Acta. 2013:1833(3):680-5.

163. Liu CX, Ranganathan S, Robinson S, Strickland DK. gamma-Secretasemediated release of the low density lipoprotein receptor-related protein 1B intracellular domain suppresses anchorage-independent growth of neuroglioma cells. J Biol Chem. 2007;282(10):7504-11.

164. Larios JA, Jausoro I, Benitez ML, Bronfman FC, Marzolo MP. Neurotrophins regulate ApoER2 proteolysis through activation of the Trk signaling pathway. BMC Neurosci. 2014;15:108.

165. Hoe HS, Rebeck GW. Regulation of ApoE receptor proteolysis by ligand binding. Brain Res Mol Brain Res. 2005;137(1-2):31-9.

166. Nishida-Fukuda $H$, Araki $R$, Shudou M, Okazaki H, Tomono $Y$, Nakayama H, Fukuda S, Sakaue T, Shirakata Y, Sayama K, et al. Ectodomain shedding of Lymphatic Vessel Endothelial Hyaluronan Receptor 1 (LYVE1) is induced by Vascular Endothelial Growth Factor a (VEGF-a). J Biol Chem. 2016;291(20):10490-500.

167. Itzhaky D, Raz N, Hollander N. The glycosylphosphatidylinositol-anchored form and the transmembrane form of CD58 are released from the cell surface upon antibody binding. Cell Immunol. 1998;187(2):151-7.

168. Rovida E, Paccagnini A, Del Rosso M, Peschon J, Dello Sbarba P. TNFalpha-converting enzyme cleaves the macrophage colony-stimulating factor receptor in macrophages undergoing activation. J Immunol. 2001;166(3):1583-9.

169. Jordens R, Thompson A, Amons R, Koning F. Human dendritic cells shed a functional, soluble form of the mannose receptor. Int Immunol. 1999;11(11):1775-80

170. Martinez-Pomares L, Mahoney JA, Kaposzta R, Linehan SA, Stahl PD, Gordon S. A functional soluble form of the murine mannose receptor is produced by macrophages in vitro and is present in mouse serum. J Biol Chem. 1998; 273(36):23376-80.

171. Cruz AC, Frank BT, Edwards ST, Dazin PF, Peschon JJ, Fang KC. Tumor necrosis factor-alpha-converting enzyme controls surface expression of c-Kit and survival of embryonic stem cell-derived mast cells. J Biol Chem. 2004; 279(7):5612-20.

172. Turner AM, Bennett LG, Lin NL, Wypych J, Bartley TD, Hunt RW, Atkins HL, Langley KE, Parker V, Martin F, et al. Identification and characterization of a soluble c-kit receptor produced by human hematopoietic cell lines. Blood. 1995;85(8):2052-8.

173. Murata M, Noda K, Fukuhara J, Kanda A, Kase S, Saito W, Ozawa Y, Mochizuki S, Kimura S, Mashima Y, et al. Soluble vascular adhesion protein-1 accumulates in proliferative diabetic retinopathy. Invest Ophthalmol Vis Sci. 2012;53(7):4055-62.

174. Salih HR, Goehlsdorf D, Steinle A. Release of MICB molecules by tumor cells: mechanism and soluble MICB in sera of cancer patients. Hum Immunol. 2006;67(3):188-95

175. Friedrich M, Henn A, Raum T, Baitus M, Matthes K, Hendrich L, Wahl J, Hoffmann P, Kischel R, Kvesic M, et al. Preclinical characterization of AMG 330, a CD3/CD33-bispecific T-cell-engaging antibody with potential for treatment of acute myelogenous leukemia. Mol Cancer Ther. 2014;13(6):1549-57.

176. Abdool A, Yeh CH, Kantarjian H, O'Brien S, Bruey J, Giles F, Albitar M. Circulating CD33 and its clinical value in acute leukemia. Exp Hematol. 2010; 38(6):462-71.

177. Biedermann B, Gil D, Bowen DT, Crocker PR. Analysis of the CD33-related siglec family reveals that Siglec-9 is an endocytic receptor expressed on subsets of acute myeloid leukemia cells and absent from normal hematopoietic progenitors. Leuk Res. 2007;31(2):211-20.

178. Collino F, Bussolati B, Gerbaudo E, Marozio L, Pelissetto S, Benedetto C, Camussi G. Preeclamptic sera induce nephrin shedding from podocytes through endothelin-1 release by endothelial glomerular cells. Am J Physiol Renal Physiol. 2008;294(5):F1185-1194.

179. Maier O, van der Heide T, Johnson R, de Vries H, Baron W, Hoekstra D. The function of neurofascin155 in oligodendrocytes is regulated by metalloprotease-mediated cleavage and ectodomain shedding. Exp Cell Res. 2006;312(4):500-11.

180. Suzuki K, Hayashi Y, Nakahara S, Kumazaki H, Prox J, Horiuchi K, Zeng M, Tanimura S, Nishiyama Y, Osawa S, et al. Activity-dependent proteolytic cleavage of neuroligin-1. Neuron. 2012;76(2):410-22.

181. Conacci-Sorrell M, Kaplan A, Raveh S, Gavert N, Sakurai T, Ben-Ze'ev A. The shed ectodomain of $\mathrm{Nr}$-CAM stimulates cell proliferation and motility, and confers cell transformation. Cancer Res. 2005;65(24):11605-12.

182. Swendeman S, Mendelson K, Weskamp G, Horiuchi K, Deutsch U, Scherle P, Hooper A, Rafii S, Blobel CP. VEGF-A stimulates ADAM17-dependent shedding of VEGFR2 and crosstalk between VEGFR2 and ERK signaling. Circ Res. 2008;103(9):916-8.

183. Waldhauer I, Steinle A. Proteolytic release of soluble UL16-binding protein 2 from tumor cells. Cancer Res. 2006;66(5):2520-6.

184. Mateos S, Calothy G, Lamballe F. The noncatalytic TrkCNC2 receptor is cleaved by metalloproteases upon neurotrophin-3 stimulation. Oncogene. 2003:22(5):740-5.

185. Biswas S, Adrian M, Weber J, Evdokimov K, Winkler M, Geraud C. Posttranslational proteolytic processing of Leda-1/Pianp involves cleavage by MMPs, ADAM10/17 and gamma-secretase. Biochem Biophys Res Commun. 2016:477(4):661-6.

186. Biswas S, Adrian M, Evdokimov K, Schledzewski K, Weber J, Winkler M, Goerdt S, Geraud C. Counter-regulation of the ligand-receptor pair Leda-1/ Pianp and Pilralpha during the LPS-mediated immune response of murine macrophages. Biochem Biophys Res Commun. 2015;464(4):1078-83.

187. Karpatova M, Tagliabue E, Castronovo V, Magnifico A, Ardini E, Morelli D, Belotti D, Colnaghi MI, Menard S. Shedding of the $67-\mathrm{kD}$ laminin receptor by human cancer cells. J Cell Biochem. 1996;60(2):226-34

188. Artigiani S, Barberis D, Fazzari P, Longati P, Angelini P, van de Loo JW, Comoglio PM, Tamagnone L. Functional regulation of semaphorin receptors by proprotein convertases. J Biol Chem. 2003;278(12):10094-101.

189. Vullhorst D, Mitchell RM, Keating C, Roychowdhury S, Karavanova I, TaoCheng $J \mathrm{H}$, Buonanno A. A negative feedback loop controls NMDA receptor function in cortical interneurons via neuregulin 2/ErbB4 signalling. Nat Commun. 2015;6:7222

190. Mattila SO, Tuusa JT, Petaja-Repo UE. The Parkinson's-disease-associated receptor GPR37 undergoes metalloproteinase-mediated N-terminal cleavage and ectodomain shedding. J Cell Sci. 2016;129(7):1366-77.

191. Magg T, Schreiner D, Solis GP, Bade EG, Hofer HW. Processing of the human protocadherin Fat1 and translocation of its cytoplasmic domain to the nucleus. Exp Cell Res. 2005;307(1):100-8.

192. Wojtalewicz N, Sadeqzadeh E, Weiss JV, Tehrani MM, Klein-Scory S, Hahn S, Schmiegel W, Warnken U, Schnolzer M, de Bock CE, et al. A soluble form of the giant cadherin Fat1 is released from pancreatic cancer cells by ADAM10 mediated ectodomain shedding. PLoS One. 2014;9(3):e90461.

193. Reiss K, Saftig P. The "a disintegrin and metalloprotease" (ADAM) family of sheddases: physiological and cellular functions. Semin Cell Dev Biol. 2009; 20(2):126-37.

194. Bouillot S, Tillet E, Carmona G, Prandini MH, Gauchez AS, Hoffmann P, Alfaidy N, Cand F, Huber P. Protocadherin-12 cleavage is a regulated process mediated by ADAM10 protein: evidence of shedding up-regulation in pre-eclampsia. J Biol Chem. 2011;286(17):15195-204.

195. Reiss K, Maretzky T, Haas IG, Schulte M, Ludwig A, Frank M, Saftig P. Regulated ADAM10-dependent ectodomain shedding of gammaprotocadherin C3 modulates cell-cell adhesion. J Biol Chem. 2006;281(31): 21735-44. 
196. Chow JP, Fujikawa A, Shimizu H, Suzuki R, Noda M. Metalloproteinase- and gamma-secretase-mediated cleavage of protein-tyrosine phosphatase receptor type Z. J Biol Chem. 2008;283(45):30879-89.

197. Ruhe JE, Streit S, Hart S, Ullrich A. EGFR signaling leads to downregulation of PTP-LAR via TACE-mediated proteolytic processing. Cell Signal. 2006;18(9):1515-27.

198. Dilaver G, van de Vorstenbosch R, Tarrega C, Rios P, Pulido R, van Aerde K, Fransen J, Hendriks W. Proteolytic processing of the receptor-type protein tyrosine phosphatase PTPBR7. FEBS J. 2007;274(1):96-108.

199. Aicher B, Lerch MM, Muller T, Schilling J, Ullrich A. Cellular redistribution of protein tyrosine phosphatases LAR and PTPsigma by inducible proteolytic processing. J Cell Biol. 1997;138(3):681-96.

200. Cousin C, Bracquart D, Contrepas A, Corvol P, Muller L, Nguyen G. Soluble form of the (pro)renin receptor generated by intracellular cleavage by furin is secreted in plasma. Hypertension. 2009;53(6):1077-82.

201. Ito H, Funahashi S, Yamauchi N, Shibahara J, Midorikawa Y, Kawai S, Kinoshita Y, Watanabe A, Hippo Y, Ohtomo T, et al. Identification of ROBO1 as a novel hepatocellular carcinoma antigen and a potential therapeutic and diagnostic target. Clin Cancer Res. 2006;12(11 Pt 1):3257-64.

202. Zhu L, Bergmeier W, Wu J, Jiang H, Stalker TJ, Cieslak M, Fan R, Boumsell L, Kumanogoh A, Kikutani $\mathrm{H}$, et al. Regulated surface expression and shedding support a dual role for semaphorin 4D in platelet responses to vascular injury. Proc Natl Acad Sci U S A. 2007;104(5):1621-6.

203. Hofmann S, Vogtle T, Bender M, Rose-John S, Nieswandt B. The SLAM family member CD84 is regulated by ADAM10 and calpain in platelets. J Thromb Haemost. 2012;10(12):2581-92.

204. Evans SF, Irmady K, Ostrow K, Kim T, Nykjaer A, Saftig P, Blobel C, Hempstead BL. Neuronal brain-derived neurotrophic factor is synthesized in excess, with levels regulated by sortilin-mediated trafficking and lysosomal degradation. J Biol Chem. 2011;286(34):29556-67.

205. Menzel S, Rissiek B, Bannas P, Jakoby T, Miksiewicz M, Schwarz N, Nissen M, Haag F, Tholey A, Koch-Nolte F. Nucleotide-induced membrane-proximal proteolysis controls the substrate specificity of T cell ecto-ADPribosyltransferase ARTC2.2. J Immunol. 2015;195(5):2057-66.

206. Dewitz C, Moller-Hackbarth K, Schweigert O, Reiss K, Chalaris A, Scheller J, Rose-John S. T-cell immunoglobulin and mucin domain 2 (TIM-2) is a target of ADAM10-mediated ectodomain shedding. FEBS J. 2014;281(1):157-74.

207. Doring G, Frank F, Boudier C, Herbert S, Fleischer B, Bellon G. Cleavage of lymphocyte surface antigens CD2, CD4, and CD8 by polymorphonuclear leukocyte elastase and cathepsin $\mathrm{G}$ in patients with cystic fibrosis. J Immunol. 1995;154(9):4842-50.

208. Calvo J, Places L, Espinosa G, Padilla O, Vila JM, Villamor N, Ingelmo M, Gallart T, Vives J, Font J, et al. Identification of a natural soluble form of human CD5. Tissue Antigens. 1999;54(2):128-37.

209. Fujimoto J, Stewart SJ, Levy R. Immunochemical analysis of the released Leu-2 (T8) molecule. J Exp Med. 1984;160(1):116-24.

210. Fujimoto J, Levy S, Levy R. Spontaneous release of the Leu-2 (T8) molecule from human T cells. J Exp Med. 1983;158(3):752-66.

211. Hebbar M, Jeannin P, Magistrelli G, Hatron PY, Hachulla E, Devulder B, Bonnefoy JY, Delneste Y. Detection of circulating soluble CD28 in patients with systemic lupus erythematosus, primary Sjogren's syndrome and systemic sclerosis. Clin Exp Immunol. 2004;136(2):388-92.

212. Liu C, Xu P, Lamouille S, Xu J, Derynck R. TACE-mediated ectodomain shedding of the type I TGF-beta receptor downregulates TGF-beta signaling. Mol Cell. 2009;35(1):26-36.

213. Kaczur V, Puskas LG, Nagy ZU, Miled N, Rebai A, Juhasz F, Kupihar Z, Zvara A, Hackler Jr L, Farid NR. Cleavage of the human thyrotropin receptor by ADAM10 is regulated by thyrotropin. J Mol Recognit. 2007;20(5):392-404.

214. Jeannin P, Magistrelli G, Aubry JP, Caron G, Gauchat JF, Renno T, Herbault N, Goetsch L, Blaecke A, Dietrich PY, et al. Soluble CD86 is a costimulatory molecule for human T Iymphocytes. Immunity. 2000;13(3):303-12.

215. Langjahr P, Diaz-Jimenez D, De la Fuente M, Rubio E, Golenbock D, Bronfman FC, Quera R, Gonzalez MJ, Hermoso MA. Metalloproteinasedependent TLR2 ectodomain shedding is involved in soluble toll-like receptor 2 (sTLR2) production. PLoS One. 2014;9(12):e104624.

216. Murakami Y, Fukui R, Motoi Y, Kanno A, Shibata T, Tanimura N, Saitoh S, Miyake K. Roles of the cleaved N-terminal TLR3 fragment and cell surface TLR3 in double-stranded RNA sensing. J Immunol. 2014;193(10):5208-17.

217. Zager RA, Johnson AC, Lund S, Randolph-Habecker J. Toll-like receptor (TLR4) shedding and depletion: acute proximal tubular cell responses to hypoxic and toxic injury. Am J Physiol Renal Physiol. 2007;292(1):F304-312.
218. Ewald SE, Lee BL, Lau L, Wickliffe KE, Shi GP, Chapman HA, Barton GM. The ectodomain of Toll-like receptor 9 is cleaved to generate a functional receptor. Nature. 2008;456(7222):658-62.

219. Chockalingam A, Cameron JL, Brooks JC, Leifer CA. Negative regulation of signaling by a soluble form of toll-like receptor 9. Eur J Immunol. 2011;41(8):2176-84

220. Chitambar CR, Zivkovic Z. Release of soluble transferrin receptor from the surface of human leukemic HL60 cells. Blood. 1989;74(2):602-8.

221. Elderbroom JL, Huang JJ, Gatza CE, Chen J, How T, Starr M, Nixon AB, Blobe GC. Ectodomain shedding of TbetaRIII is required for TbetaRIII-mediated suppression of TGF-beta signaling and breast cancer migration and invasion. Mol Biol Cell. 2014;25(16):2320-32.

222. Gattis JL, Washington AV, Chisholm MM, Quigley L, Szyk A, McVicar DW, Lubkowski J. The structure of the extracellular domain of triggering receptor expressed on myeloid cells like transcript-1 and evidence for a naturally occurring soluble fragment. J Biol Chem. 2006;281(19):13396-403.

223. Gomez-Pina V, Soares-Schanoski A, Rodriguez-Rojas A, Del Fresno C, Garcia F, Vallejo-Cremades MT, Fernandez-Ruiz I, Arnalich F, Fuentes-Prior P, LopezCollazo E. Metalloproteinases shed TREM-1 ectodomain from lipopolysaccharide-stimulated human monocytes. J Immunol. 2007;179(6): 4065-73.

224. Wunderlich P, Glebov K, Kemmerling N, Tien NT, Neumann H, Walter J. Sequential proteolytic processing of the triggering receptor expressed on myeloid cells-2 (TREM2) protein by ectodomain shedding and gammasecretase-dependent intramembranous cleavage. J Biol Chem. 2013;288(46): 33027-36.

225. Hakozaki A, Yoda M, Tohmonda T, Furukawa M, Hikata T, Uchikawa S, Takaishi H, Matsumoto M, Chiba K, Horiuchi K, et al. Receptor activator of NF-kappaB (RANK) ligand induces ectodomain shedding of RANK in murine RAW264.7 macrophages. J Immunol. 2010;184(5):2442-8.

226. Tam EM, Morrison CJ, Wu YI, Stack MS, Overall CM. Membrane protease proteomics: Isotope-coded affinity tag MS identification of undescribed MT1-matrix metalloproteinase substrates. Proc Natl Acad Sci U S A. 2004; 101(18):6917-22.

227. He Y, Wortmann A, Burke LJ, Reid JC, Adams MN, Abdul-Jabbar I, Quigley JP, Leduc R, Kirchhofer D, Hooper JD. Proteolysis-induced N-terminal ectodomain shedding of the integral membrane glycoprotein CUB domaincontaining protein 1 (CDCP1) is accompanied by tyrosine phosphorylation of its C-terminal domain and recruitment of SrC and PKCdelta. J Biol Chem. 2010;285(34):26162-73.

228. Zhang S, Yeap XY, Grigoryeva L, Dehn S, DeBerge M, Tye M, Rostlund E, Schrijvers D, Zhang ZJ, Sumagin R, et al. Cardiomyocytes induce macrophage receptor shedding to suppress phagocytosis. J Mol Cell Cardiol. 2015;87:171-9.

229. O'Bryan JP, Fridell YW, Koski R, Varnum B, Liu ET. The transforming receptor tyrosine kinase, $\mathrm{Axl}$, is post-translationally regulated by proteolytic cleavage. J Biol Chem. 1995:270(2):551-7.

230. Budagian V, Bulanova E, Orinska Z, Duitman E, Brandt K, Ludwig A, Hartmann D, Lemke G, Saftig P, Bulfone-Paus S. Soluble Axl is generated by ADAM10-dependent cleavage and associates with Gas6 in mouse serum. Mol Cell Biol. 2005;25(21):9324-39.

231. Lyu J, Yamamoto V, Lu W. Cleavage of the Wht receptor Ryk regulates neuronal differentiation during cortical neurogenesis. Dev Cell. 2008; 15(5):773-80

232. Rahimi N, Golde TE, Meyer RD. Identification of ligand-induced proteolytic cleavage and ectodomain shedding of VEGFR-1/FLT1 in leukemic cancer cells. Cancer Res. 2009;69(6):2607-14.

233. Donners MM, Wolfs IM, Olieslagers S, Mohammadi-Motahhari Z, Tchaikovski V, Heeneman S, van Buul JD, Caolo V, Molin DG, Post MJ, et al. A disintegrin and metalloprotease 10 is a novel mediator of vascular endothelial growth factor-induced endothelial cell function in angiogenesis and is associated with atherosclerosis. Arterioscler Thromb Vasc Biol. 2010;30(11):2188-95.

234. Malapeira J, Esselens C, Bech-Serra JJ, Canals F, Arribas J. ADAM17 (TACE) regulates TGFbeta signaling through the cleavage of vasorin. Oncogene. 2011;30(16):1912-22.

235. Radichev IA, Maneva-Radicheva LV, Amatya C, Parker C, Ellefson J, Wasserfall C, Atkinson M, Burn P, Savinov AY. Nardilysin-dependent proteolysis of cellassociated VTCN1 (B7-H4) marks type 1 diabetes development. Diabetes. 2014;63(10):3470-82.

236. Ehsani S, Salehzadeh A, Huo H, Reginold W, Pocanschi CL, Ren H, Wang H, So K, Sato C, Mehrabian M, et al. LIV-1 ZIP ectodomain shedding in prion- 
infected mice resembles cellular response to transition metal starvation. J Mol Biol. 2012:422(4):556-74.

237. Kambe T, Andrews GK. Novel proteolytic processing of the ectodomain of the zinc transporter ZIP4 (SLC39A4) during zinc deficiency is inhibited by acrodermatitis enteropathica mutations. Mol Cell Biol. 2009;29(1):129-39.

238. Tang J, Bond JS. Maturation of secreted meprin alpha during biosynthesis: role of the furin site and identification of the $\mathrm{COOH}$-terminal amino acids of the mouse kidney metalloprotease subunit. Arch Biochem Biophys. 1998; 349(1):192-200.

239. Xu Z, Zhang T, Zhuang R, Zhang Y, Jia W, Song C, Yang K, Yang A, Jin B. Increased levels of soluble CD226 in sera accompanied by decreased membrane CD226 expression on peripheral blood mononuclear cells from cancer patients. BMC Immunol. 2009;10:34.

240. Zhang G, Hou J, Shi J, Yu G, Lu B, Zhang X. Soluble CD276 (B7-H3) is released from monocytes, dendritic cells and activated $T$ cells and is detectable in normal human serum. Immunology. 2008;123(4):538-46.

241. Baleeiro RB, Barbuto JA. Local secretion/shedding of tumor-derived CD83 molecules as a novel tumor escape mechanism. Mol Immunol. 2008;45(12):3502-4.

242. Shuo T, Aono S, Nakanishi K, Tokita Y, Kuroda Y, Ida M, Matsui F, Maruyama $H$, Kaji T, Oohira A. Ectodomain shedding of neuroglycan C, a brain-specific chondroitin sulfate proteoglycan, by TIMP-2- and TIMP-3-sensitive proteolysis. J Neurochem. 2007;102(5):1561-8.

243. Hawinkels LJ, Kuiper P, Wiercinska E, Verspaget HW, Liu Z, Pardali E, Sier CF, ten Dijke P. Matrix metalloproteinase-14 (MT1-MMP)-mediated endoglin shedding inhibits tumor angiogenesis. Cancer Res. 2010;70(10):4141-50.

244. Kaitu'U-Lino TJ, Palmer KR, Whitehead CL, Williams E, Lappas M, Tong S. MMP-14 is expressed in preeclamptic placentas and mediates release of soluble endoglin. Am J Pathol. 2012;180(3):888-94.

245. Steinberg F, Zhuang L, Beyeler M, Kalin RE, Mullis PE, Brandli AW, Trueb B. The FGFRL1 receptor is shed from cell membranes, binds fibroblast growth factors (FGFs), and antagonizes FGF signaling in Xenopus embryos. J Biol Chem. 2010;285(3):2193-202.

246. Carey BW, Kim DY, Kovacs DM. Presenilin/gamma-secretase and alphasecretase-like peptidases cleave human MHC Class I proteins. Biochem J. 2007:401(1):121-7.

247. Golubkov VS, Strongin AY. Insights into ectodomain shedding and processing of protein-tyrosine pseudokinase 7 (PTK7). J Biol Chem. 2012; 287(50):42009-18.

248. McElroy B, Powell JC, McCarthy JV. The insulin-like growth factor 1 (IGF-1) receptor is a substrate for gamma-secretase-mediated intramembrane proteolysis. Biochem Biophys Res Commun. 2007;358(4):1136-41.

249. Sevenich L, Joyce JA. Pericellular proteolysis in cancer. Genes Dev. 2014; 28(21):2331-47.

250. Sollid LM, Kvale D, Brandtzaeg P, Markussen G, Thorsby E. Interferon-gamma enhances expression of secretory component, the epithelial receptor for polymeric immunoglobulins. J Immunol. 1987;138(12):4303-6.

251. Menschikowski M, Hagelgans A, Eisenhofer G, Tiebel O, Siegert G. Reducing agents induce thrombomodulin shedding in human endothelial cells. Thromb Res. 2010;126(2):e88-93.

252. Marron MB, Singh H, Tahir TA, Kavumkal J, Kim HZ, Koh GY, Brindle NP. Regulated proteolytic processing of Tie1 modulates ligand responsiveness of the receptor-tyrosine kinase Tie2. J Biol Chem. 2007;282(42):30509-17.

253. Toth $A B$, Terauchi $A$, Zhang $L Y$, Johnson-Venkatesh EM, Larsen DJ, Sutton MA, Umemori $\mathrm{H}$. Synapse maturation by activity-dependent ectodomain shedding of SIRPalpha. Nat Neurosci. 2013;16(10):1417-25.

254. Singh RJ, Mason JC, Lidington EA, Edwards DR, Nuttall RK, Khokha R, Knauper V, Murphy G, Gavrilovic J. Cytokine stimulated vascular cell adhesion molecule-1 (VCAM-1) ectodomain release is regulated by TIMP-3. Cardiovasc Res. 2005;67(1):39-49.

255. Shirakabe K, Hattori S, Seiki M, Koyasu S, Okada Y. VIP36 protein is a target of ectodomain shedding and regulates phagocytosis in macrophage Raw 264.7 cells. J Biol Chem. 2011;286(50):43154-63.

256. Airas L, Niemela J, Salmi M, Puurunen T, Smith DJ, Jalkanen S. Differential regulation and function of CD73, a glycosyl-phosphatidylinositol-linked 70kD adhesion molecule, on lymphocytes and endothelial cells. J Cell Biol. 1997;136(2):421-31.

257. Will H, Atkinson SJ, Butler GS, Smith B, Murphy G. The soluble catalytic domain of membrane type 1 matrix metalloproteinase cleaves the propeptide of progelatinase $\mathrm{A}$ and initiates autoproteolytic activation. Regulation by TIMP-2 and TIMP-3. J Biol Chem. 1996;271(29):17119-23.
258. Chang GW, Stacey M, Kwakkenbos MJ, Hamann J, Gordon S, Lin HH. Proteolytic cleavage of the EMR2 receptor requires both the extracellular stalk and the GPS motif. FEBS Lett. 2003;547(1-3):145-50.

259. Hughey RP, Bruns JB, Kinlough CL, Harkleroad KL, Tong Q, Carattino MD, Johnson JP, Stockand JD, Kleyman TR. Epithelial sodium channels are activated by furin-dependent proteolysis. J Biol Chem. 2004;279(18):18111-4

260. Carattino MD, Hughey RP, Kleyman TR. Proteolytic processing of the epithelial sodium channel gamma subunit has a dominant role in channel activation. J Biol Chem. 2008;283(37):25290-5.

261. Ohtsu H, Dempsey PJ, Eguchi S. ADAMs as mediators of EGF receptor transactivation by G protein-coupled receptors. Am J Physiol Cell Physiol. 2006;291(1):C1-10

262. Schafer B, Marg B, Gschwind A, Ullrich A. Distinct ADAM metalloproteinases regulate $G$ protein-coupled receptor-induced cell proliferation and survival. J Biol Chem. 2004;279(46):47929-38.

263. Nagathihalli NS, Beesetty Y, Lee W, Washington MK, Chen X, Lockhart AC, Merchant NB. Novel mechanistic insights into ectodomain shedding of EGFR Ligands Amphiregulin and TGF-alpha: impact on gastrointestinal cancers driven by secondary bile acids. Cancer Res. 2014;74(7):2062-72.

264. Paliga K, Peraus G, Kreger S, Durrwang U, Hesse L, Multhaup G, Masters CL, Beyreuther K, Weidemann A. Human amyloid precursor-like protein 1-cDNA cloning, ectopic expression in COS-7 cells and identification of soluble forms in the cerebrospinal fluid. Eur J Biochem. 1997;250(2):354-63.

265. Scheinfeld MH, Ghersi E, Laky K, Fowlkes BJ, D'Adamio L. Processing of betaamyloid precursor-like protein-1 and -2 by gamma-secretase regulates transcription. J Biol Chem. 2002;277(46):44195-201.

266. Endres K, Postina R, Schroeder A, Mueller U, Fahrenholz F. Shedding of the amyloid precursor protein-like protein APLP2 by disintegrinmetalloproteinases. FEBS J. 2005:272(22):5808-20.

267. Lambert DW, Yarski M, Warner FJ, Thornhill P, Parkin ET, Smith Al, Hooper NM, Turner AJ. Tumor necrosis factor-alpha convertase (ADAM17) mediates regulated ectodomain shedding of the severe-acute respiratory syndromecoronavirus (SARS-CoV) receptor, angiotensin-converting enzyme-2 (ACE2). J Biol Chem. 2005:280(34):30113-9.

268. Haga S, Yamamoto N, Nakai-Murakami C, Osawa Y, Tokunaga K, Sata T, Sasazuki T, Ishizaka Y. Modulation of TNF-alpha-converting enzyme by the spike protein of SARS-COV and ACE2 induces TNF-alpha production and facilitates viral entry. Proc Natl Acad Sci U S A. 2008;105(22):7809-14.

269. Rescher U, Goebeler V, Wilbers A, Gerke V. Proteolytic cleavage of annexin 1 by human leukocyte elastase. Biochim Biophys Acta. 2006;1763(11):1320-4.

270. Tsunezumi J, Yamamoto K, Higashi S, Miyazaki K. Matrilysin (matrix metalloprotease-7) cleaves membrane-bound annexin II and enhances binding of tissue-type plasminogen activator to cancer cell surfaces. FEBS J. 2008;275(19):4810-23.

271. Jiang J, Wu S, Wang W, Chen S, Peng J, Zhang X, Wu Q. Ectodomain shedding and autocleavage of the cardiac membrane protease corin. J Biol Chem. 2011;286(12):10066-72.

272. Kikkawa Y, Miwa T, Tanimizu N, Kadoya Y, Ogawa T, Katagiri F, Hozumi K, Nomizu M, Mizuguchi T, Hirata K, et al. Soluble Lutheran/basal cell adhesion molecule is detectable in plasma of hepatocellular carcinoma patients and modulates cellular interaction with laminin-511 in vitro. Exp Cell Res. 2014; 328(1):197-206.

273. Tang Y, Kesavan P, Nakada MT, Yan L. Tumor-stroma interaction: positive feedback regulation of extracellular matrix metalloproteinase inducer (EMMPRIN) expression and matrix metalloproteinase-dependent generation of soluble EMMPRIN. Mol Cancer Res. 2004;2(2):73-80.

274. Egawa N, Koshikawa N, Tomari T, Nabeshima K, Isobe T, Seiki M. Membrane type 1 matrix metalloproteinase (MT1-MMP/MMP-14) cleaves and releases a 22-kDa extracellular matrix metalloproteinase inducer (EMMPRIN) fragment from tumor cells. J Biol Chem. 2006;281(49):37576-85.

275. Petruszak JA, Nehme CL, Bartles JR. Endoproteolytic cleavage in the extracellular domain of the integral plasma membrane protein CE9 precedes its redistribution from the posterior to the anterior tail of the rat spermatozoon during epididymal maturation. J Cell Biol. 1991;114(5):917-27.

276. Hussain I, Hawkins J, Shikotra A, Riddell DR, Faller A, Dingwall C. Characterization of the ectodomain shedding of the beta-site amyloid precursor protein-cleaving enzyme 1 (BACE1). J Biol Chem. 2003;278(38): 36264-8.

277. Hussain I, Christie G, Schneider K, Moore S, Dingwall C. Prodomain processing of Asp1 (BACE2) is autocatalytic. J Biol Chem. 2001;276(26): 23322-8. 
278. Reiss K, Maretzky T, Ludwig A, Tousseyn T, de Strooper B, Hartmann D, Saftig P. ADAM10 cleavage of $\mathrm{N}$-cadherin and regulation of cell-cell adhesion and beta-catenin nuclear signalling. EMBO J. 2005;24(4):742-52

279. Derycke L, De Wever O, Stove V, Vanhoecke B, Delanghe J, Depypere H, Bracke M. Soluble N-cadherin in human biological fluids. Int I Cancer. 2006; 119(12):2895-900.

280. Ribeiro AS, Albergaria A, Sousa B, Correia AL, Bracke M, Seruca R, Schmitt FC, Paredes J. Extracellular cleavage and shedding of P-cadherin: a mechanism underlying the invasive behaviour of breast cancer cells. Oncogene. 2010; 29(3):392-402.

281. Bothe MK, Mundhenk L, Beck CL, Kaup M, Gruber AD. Impaired autoproteolytic cleavage of mCLCA6, a murine integral membrane protein expressed in enterocytes, leads to cleavage at the plasma membrane instead of the endoplasmic reticulum. Mol Cells. 2012;33(3):251-7.

282. Hata S, Fujishige S, Araki Y, Kato N, Araseki M, Nishimura M, Hartmann D, Saftig P, Fahrenholz F, Taniguchi M, et al. Alcadein cleavages by amyloid beta-precursor protein (APP) alpha- and gamma-secretases generate small peptides, p3-Alcs, indicating Alzheimer disease-related gamma-secretase dysfunction. J Biol Chem. 2009;284(52):36024-33.

283. Vogt L, Schrimpf SP, Meskenaite V, Frischknecht R, Kinter J, Leone DP, Ziegler U, Sonderegger P. Calsyntenin-1, a proteolytically processed postsynaptic membrane protein with a cytoplasmic calcium-binding domain. Mol Cell Neurosci. 2001;17(1):151-66.

284. Hockla A, Radisky DC, Radisky ES. Mesotrypsin promotes malignant growth of breast cancer cells through shedding of CD109. Breast Cancer Res Treat. 2010;124(1):27-38.

285. Rosso O, Piazza T, Bongarzone I, Rossello A, Mezzanzanica D, Canevari S, Orengo AM, Puppo A, Ferrini S, Fabbi M. The ALCAM shedding by the metalloprotease ADAM17/TACE is involved in motility of ovarian carcinoma cells. Mol Cancer Res. 2007;5(12):1246-53.

286. Loenen WA, De Vries E, Gravestein LA, Hintzen RQ, Van Lier RA, Borst J. The CD27 membrane receptor, a lymphocyte-specific member of the nerve growth factor receptor family, gives rise to a soluble form by protein processing that does not involve receptor endocytosis. Eur J Immunol. 1992;22(2):447-55.

287. Nagano O, Murakami D, Hartmann D, De Strooper B, Saftig P, Iwatsubo T, Nakajima M, Shinohara M, Saya H. Cell-matrix interaction via CD44 is independently regulated by different metalloproteinases activated in response to extracellular $\mathrm{Ca}(2+)$ influx and PKC activation. J Cell Biol. 2004; 165(6):893-902.

288. Hakulinen J, Meri S. Shedding and enrichment of the glycolipid-anchored complement lysis inhibitor protectin (CD59) into milk fat globules. Immunology. 1995;85(3):495-501.

289. Nagara Y, Hagiyama M, Hatano N, Futai E, Suo S, Takaoka Y, Murakami Y, Ito A, Ishiura S. Tumor suppressor cell adhesion molecule 1 (CADM1) is cleaved by a disintegrin and metalloprotease 10 (ADAM10) and subsequently cleaved by gamma-secretase complex. Biochem Biophys Res Commun. 2012:417(1):462-7.

290. Asher RA, Morgenstern DA, Properzi F, Nishiyama A, Levine JM, Fawcett JW. Two separate metalloproteinase activities are responsible for the shedding and processing of the NG2 proteoglycan in vitro. Mol Cell Neurosci. 2005; 29(1):82-96

291. Vaisanen MR, Vaisanen T, Pihlajaniemi T. The shed ectodomain of type XIII collagen affects cell behaviour in a matrix-dependent manner. Biochem J. 2004;380(Pt 3):685-93.

292. Zimina EP, Fritsch A, Schermer B, Bakulina AY, Bashkurov M, Benzing T, Bruckner-Tuderman L. Extracellular phosphorylation of collagen XVII by ecto-casein kinase 2 inhibits ectodomain shedding. J Biol Chem. 2007; 282(31):22737-46.

293. Hashimoto T, Wakabayashi T, Watanabe A, Kowa H, Hosoda R, Nakamura A, Kanazawa I, Arai T, Takio K, Mann DM, et al. CLAC: a novel Alzheimer amyloid plaque component derived from a transmembrane precursor, CLAC-P/collagen type XXV. EMBO J. 2002;21(7):1524-34.

294. Rozanov DV, Ghebrehiwet B, Postnova TI, Eichinger A, Deryugina El, Strongin AY. The hemopexin-like C-terminal domain of membrane type 1 matrix metalloproteinase regulates proteolysis of a multifunctional protein, gC1qR. J Biol Chem. 2002;277(11):9318-25.

295. Reddy P, Caras I, Krieger M. Effects of O-linked glycosylation on the cell surface expression and stability of decay-accelerating factor, a glycophospholipid-anchored membrane protein. J Biol Chem. 1989; 264(29):17329-36.
296. Houri N, Huang KC, Nalbantoglu J. The Coxsackievirus and Adenovirus Receptor (CAR) undergoes ectodomain shedding and regulated intramembrane proteolysis (RIP). PLoS One. 2013;8(8):e73296.

297. Tsunezumi J, Higashi S, Miyazaki K. Matrilysin (MMP-7) cleaves C-type lectin domain family 3 member A (CLEC3A) on tumor cell surface and modulates its cell adhesion activity. J Cell Biochem. 2009;106(4):693-702.

298. Wilkinson L, Kolle G, Wen D, Piper M, Scott J, Little M. CRIM1 regulates the rate of processing and delivery of bone morphogenetic proteins to the cell surface. J Biol Chem. 2003;278(36):34181-8.

299. James RE, Hoover KM, Bulgari D, McLaughlin CN, Wilson CG, Wharton KA, Levitan ES, Broihier HT. Crimpy enables discrimination of presynaptic and postsynaptic pools of a BMP at the Drosophila neuromuscular junction. Dev Cell. 2014;31(5):586-98.

300. Meissner U, Blum H, Schnare M, Rollinghoff M, Gessner A. A soluble form of the murine common gamma chain is present at high concentrations in vivo and suppresses cytokine signaling. Blood. 2001;97(1):183-91.

301. Kveiborg M, Albrechtsen R, Couchman JR, Wewer UM. Cellular roles of ADAM12 in health and disease. Int J Biochem Cell Biol. 2008;40(9):1685-702.

302. Weiske J, Schoneberg T, Schroder W, Hatzfeld M, Tauber R, Huber O. The fate of desmosomal proteins in apoptotic cells. J Biol Chem. 2001; 276(44):41175-81.

303. Park SW, Yoon HJ, Lee HB, Hooper NM, Park HS. Nitric oxide inhibits the shedding of the glycosylphosphatidylinositol-anchored dipeptidase from porcine renal proximal tubules. Biochem J. 2002;364(Pt 1):211-8.

304. Lee HD, Kim YH, Koo BH, Kim DS. The ADAM15 ectodomain is shed from secretory exosomes. BMB Rep. 2015;48(5):277-82.

305. Kang T, Park HI, Suh Y, Zhao YG, Tschesche H, Sang QX. Autolytic processing at Glu586-Ser587 within the cysteine-rich domain of human adamalysin 19/disintegrin-metalloproteinase 19 is necessary for its proteolytic activity. J Biol Chem. 2002;277(50):48514-22.

306. Mochizuki S, Shimoda M, Shiomi T, Fujii Y, Okada Y. ADAM28 is activated by MMP-7 (matrilysin-1) and cleaves insulin-like growth factor binding protein3. Biochem Biophys Res Commun. 2004;315(1):79-84.

307. Goth CK, Halim A, Khetarpal SA, Rader DJ, Clausen H, Schjoldager KT. A systematic study of modulation of ADAM-mediated ectodomain shedding by site-specific O-glycosylation. Proc Natl Acad Sci U S A. 2015;112(47):14623-8,

308. Twito T, Chen Z, Khatri I, Wong K, Spaner D, Gorczynski R. Ectodomain shedding of CD200 from the B-CLL cell surface is regulated by ADAM28 expression. Leuk Res. 2013;37(7):816-21.

309. Schlomann U, Wildeboer D, Webster A, Antropova O, Zeuschner D, Knight CG, Docherty AJ, Lambert M, Skelton L, Jockusch H, et al. The metalloprotease disintegrin ADAM8. Processing by autocatalysis is required for proteolytic activity and cell adhesion. J Biol Chem. 2002;277(50):48210-9.

310. Bozzi M, Inzitari R, Sbardell D, Monaco S, Pavoni E, Gioia M, Marini S, Morlacchi S, Sciandra F, Castagnola M, et al. Enzymatic processing of betadystroglycan recombinant ectodomain by MMP-9: identification of the main cleavage site. IUBMB Life. 2009;61(12):1143-52.

311. Zhong D, Saito F, Saito Y, Nakamura A, Shimizu T, Matsumura K. Characterization of the protease activity that cleaves the extracellular domain of beta-dystroglycan. Biochem Biophys Res Commun. 2006; 345(2):867-71.

312. Ku SK, Yang EJ, Song KS, Bae JS. Rosmarinic acid down-regulates endothelial protein $\mathrm{C}$ receptor shedding in vitro and in vivo. Food Chem Toxicol. 2013:59:311-5.

313. Grantcharova E, Furkert J, Reusch HP, Krell HW, Papsdorf G, Beyermann M, Schulein R, Rosenthal W, Oksche A. The extracellular N terminus of the endothelin B (ETB) receptor is cleaved by a metalloprotease in an agonistdependent process. J Biol Chem. 2002;277(46):43933-41.

314. Oricchio E, Nanjangud G, Wolfe AL, Schatz JH, Mavrakis K, Jiang M, Liu X, Bruno J, Heguy A, Olshen AB, et al. The Eph-receptor A7 is a soluble tumor suppressor for follicular lymphoma. Cell. 2011;147(3):554-64.

315. Chen EI, Li W, Godzik A, Howard EW, Smith JW. A residue in the S2 subsite controls substrate selectivity of matrix metalloproteinase-2 and matrix metalloproteinase-9. J Biol Chem. 2003;278(19):17158-63.

316. Lin KT, Sloniowski S, Ethell DW, Ethell IM. Ephrin-B2-induced cleavage of EphB2 receptor is mediated by matrix metalloproteinases to trigger cell repulsion. J Biol Chem. 2008;283(43):28969-79.

317. Tanaka M, Sasaki K, Kamata R, Sakai R. The C-terminus of ephrin-B1 regulates metalloproteinase secretion and invasion of cancer cells. J Cell Sci. 2007: 120(Pt 13):2179-89. 
318. Bryan RT, Regan HL, Pirrie SJ, Devall AJ, Cheng KK, Zeegers MP, James ND, Knowles MA, Ward DG. Protein shedding in urothelial bladder cancer: prognostic implications of soluble urinary EGFR and EpCAM. Br J Cancer. 2015;112(6):1052-8.

319. Wilken JA, Perez-Torres M, Nieves-Alicea R, Cora EM, Christensen TA, Baron AT, Maihle NJ. Shedding of soluble epidermal growth factor receptor (sEGFR) is mediated by a metalloprotease/fibronectin/integrin axis and inhibited by cetuximab. Biochemistry. 2013;52(26):4531-40.

320. Slack BE, Siniaia MS, Blusztajn JK. Collagen type I selectively activates ectodomain shedding of the discoidin domain receptor 1 : involvement of Src tyrosine kinase. J Cell Biochem. 2006;98(3):672-84.

321. Wyble CW, Hynes KL, Kuchibhotla J, Marcus BC, Hallahan D, Gewertz BL. TNF-alpha and IL-1 upregulate membrane-bound and soluble E-selectin through a common pathway. J Surg Res. 1997;73(2):107-12.

322. Levi E, Fridman R, Miao HQ, Ma YS, Yayon A, Vlodavsky I. Matrix metalloproteinase 2 releases active soluble ectodomain of fibroblast growth factor receptor 1. Proc Natl Acad Sci U S A. 1996;93(14):7069-74.

323. Garton KJ, Gough PJ, Blobel CP, Murphy G, Greaves DR, Dempsey PJ, Raines EW. Tumor necrosis factor-alpha-converting enzyme (ADAM17) mediates the cleavage and shedding of fractalkine (CX3CL1). J Biol Chem. 2001; 276(41):37993-8001.

324. Denault J, Bissonnette L, Longpre J, Charest G, Lavigne P, Leduc R. Ectodomain shedding of furin: kinetics and role of the cysteine-rich region. FEBS Lett. 2002;527(1-3):309-14.

325. Plaimauer B, Mohr G, Wernhart W, Himmelspach M, Dorner F, Schlokat U. 'Shed' furin: mapping of the cleavage determinants and identification of its C-terminus. Biochem J. 2001;354(Pt 3):689-95.

326. Eshed Y, Feinberg K, Carey DJ, Peles E. Secreted gliomedin is a perinodal matrix component of peripheral nerves. J Cell Biol. 2007;177(3):551-62.

327. Wei J, Lin $\mathrm{CH}, \mathrm{Wu} \mathrm{H}$, Jin Y, Lee YH, Wu JY. Activity-dependent cleavage of brain glutamic acid decarboxylase 65 by calpain. J Neurochem. 2006;98(5): 1688-95.

328. Ganor Y, Teichberg VI, Levite M. TCR activation eliminates glutamate receptor GluR3 from the cell surface of normal human T cells, via an autocrine/paracrine granzyme B-mediated proteolytic cleavage. J Immunol. 2007;178(2):683-92.

329. Pauly T, Ratliff M, Pietrowski E, Neugebauer R, Schlicksupp A, Kirsch J, Kuhse J. Activity-dependent shedding of the NMDA receptor glycine binding site by matrix metalloproteinase 3: a PUTATIVE mechanism of postsynaptic plasticity. PLoS One. 2008;3(7):e2681.

330. Song Y, Nestor KE, MCFarland DC, Velleman SG. Effect of glypican-1 covalently attached chains on turkey myogenic satellite cell proliferation, differentiation, and fibroblast growth factor 2 responsiveness. Poult Sci. 2010;89(1):123-34

331. Capurro M, Filmus J. Glypican-3 as a serum marker for hepatocellular carcinoma. Cancer Res. 2005;65(1):372. author reply 372-373.

332. De Cat B, Muyldermans SY, Coomans C, Degeest G, Vanderschueren B, Creemers J, Biemar F, Peers B, David G. Processing by proprotein convertases is required for glypican-3 modulation of cell survival, Wnt signaling, and gastrulation movements. J Cell Biol. 2003;163(3):625-35.

333. Moriguchi T, Haraguchi K, Ueda N, Okada M, Furuya T, Akiyama T. DREG, a developmentally regulated $\mathrm{G}$ protein-coupled receptor containing two conserved proteolytic cleavage sites. Genes Cells. 2004;9(6):549-60.

334. Yang TY, Chiang NY, Tseng WY, Pan HL, Peng YM, Shen JJ, Wu KA, Kuo ML, Chang GW, Lin HH. Expression and immunoaffinity purification of recombinant soluble human GPR56 protein for the analysis of GPR56 receptor shedding by ELISA. Protein Expr Purif. 2015;109:85-92.

335. Zhang Y, Guan R, Jiang J, Kopchick JJ, Black RA, Baumann G, Frank SJ. Growth hormone (GH)-induced dimerization inhibits phorbol esterstimulated GH receptor proteolysis. J Biol Chem. 2001;276(27):24565-73.

336. Mizuno K, Tanoue Y, Okano I, Harano T, Takada K, Nakamura T. Purification and characterization of hepatocyte growth factor (HGF)converting enzyme: activation of pro-HGF. Biochem Biophys Res Commun. 1994;198(3):1161-9.

337. Kopitz C, Gerg M, Bandapalli OR, Ister D, Pennington CJ, Hauser S, Flechsig C, Krell HW, Antolovic D, Brew K, et al. Tissue inhibitor of metalloproteinases-1 promotes liver metastasis by induction of hepatocyte growth factor signaling. Cancer Res. 2007;67(18):8615-23.

338. Chalupsky K, Kanchev I, Zbodakova O, Buryova H, Jirouskova M, Korinek V, Gregor M, Sedlacek R. ADAM10/17-dependent release of soluble c-Met correlates with hepatocellular damage. Folia Biol. 2013;59(2):76-86.
339. Becker-Herman S, Arie G, Medvedovsky H, Kerem A, Shachar I. CD74 is a member of the regulated intramembrane proteolysis-processed protein family. Mol Biol Cell. 2005;16(11):5061-9.

340. The soluble insulin receptor study group. Soluble insulin receptor ectodomain is elevated in the plasma of patients with diabetes. Diabetes. 2007;56(8):2028-2035.

341. Teixido J, Parker CM, Kassner PD, Hemler ME. Functional and structural analysis of VLA-4 integrin alpha 4 subunit cleavage. J Biol Chem. 1992; 267(3):1786-91.

342. Pawar SC, Demetriou MC, Nagle RB, Bowden GT, Cress AE. Integrin alpha6 cleavage: a novel modification to modulate cell migration. Exp Cell Res. 2007;313(6):1080-9.

343. Ratnikov BI, Rozanov DV, Postnova TI, Baciu PG, Zhang H, DiScipio RG, Chestukhina GG, Smith JW, Deryugina El, Strongin AY. An alternative processing of integrin alpha(v) subunit in tumor cells by membrane type-1 matrix metalloproteinase. J Biol Chem. 2002;277(9):7377-85.

344. Majda JA, Gerner EW, Vanlandingham B, Gehlsen KR, Cress AE. Heat shockinduced shedding of cell surface integrins in A549 human lung tumor cells in culture. Exp Cell Res. 1994;210(1):46-51.

345. Kryczka J, Stasiak M, Dziki L, Mik M, Dziki A, Cierniewski C. Matrix metalloproteinase-2 cleavage of the beta1 integrin ectodomain facilitates colon cancer cell motility. J Biol Chem. 2012;287(43):36556-66.

346. Pal-Ghosh S, Blanco T, Tadvalkar G, Pajoohesh-Ganji A, Parthasarathy A, Zieske JD, Stepp MA. MMP9 cleavage of the beta4 integrin ectodomain leads to recurrent epithelial erosions in mice. J Cell Sci. 2011;124(Pt 15):2666-75.

347. Tsakadze NL, Sithu SD, Sen U, English WR, Murphy G, D'Souza SE. Tumor necrosis factor-alpha-converting enzyme (TACE/ADAM-17) mediates the ectodomain cleavage of intercellular adhesion molecule-1 (ICAM-1). J Biol Chem. 2006;281 (6):3157-64.

348. Saleh AZ, Fang AT, Arch AE, Neupane D, El Fiky A, Krolewski JJ. Regulated proteolysis of the IFNaR2 subunit of the interferon-alpha receptor. Oncogene. 2004;23(42):7076-86.

349. Mortier E, Bernard J, Plet A, Jacques Y. Natural, proteolytic release of a soluble form of human IL-15 receptor alpha-chain that behaves as a specific, high affinity IL-15 antagonist. J Immunol. 2004;173(3):1681-8.

350. Bellora F, Castriconi R, Doni A, Cantoni C, Moretta L, Mantovani A, Moretta A, Bottino C. M-CSF induces the expression of a membrane-bound form of IL-18 in a subset of human monocytes differentiating in vitro toward macrophages. Eur J Immunol. 2012;42(6):1618-26.

351. Kawaguchi N, Horiuchi K, Becherer JD, Toyama Y, Besmer P, Blobel CP. Different ADAMs have distinct influences on Kit ligand processing: phorbolester-stimulated ectodomain shedding of Kitl1 by ADAM17 is reduced by ADAM19. J Cell Sci. 2007;120(Pt 6):943-52.

352. Shimomura T, Denda K, Kawaguchi T, Matsumoto K, Miyazawa K, Kitamura N. Multiple sites of proteolytic cleavage to release soluble forms of hepatocyte growth factor activator inhibitor type 1 from a transmembrane form. J Biochem. 1999;126(5):821-8.

353. Ito N, Nomura S, Iwase A, Ito T, Kikkawa F, Tsujimoto M, Ishiura S, Mizutani S. ADAMs, a disintegrin and metalloproteinases, mediate shedding of oxytocinase. Biochem Biophys Res Commun. 2004;314(4):1008-13.

354. Ouyang W, Xue J, Liu J, Jia W, Li Z, Xie X, Liu X, Jian J, Li Q, Zhu Y, et al. Establishment of an ELISA system for determining soluble LAIR-1 levels in sera of patients with HFRS and kidney transplant. J Immunol Methods. 2004; 292(1-2):109-17.

355. Bazil V, Strominger JL. Metalloprotease and serine protease are involved in cleavage of CD43, CD44, and CD16 from stimulated human granulocytes. Induction of cleavage of L-selectin via CD16. J Immunol. 1994;152(3):1314-22.

356. Bazil V, Strominger JL. CD43, the major sialoglycoprotein of human leukocytes, is proteolytically cleaved from the surface of stimulated lymphocytes and granulocytes. Proc Natl Acad Sci U S A. 1993;90(9):3792-6.

357. Elavarasu S, Suthanthiran T, Thangavelu A, Saravanan J, Selvaraj S, Mohandas L. Comparative analysis of gingival crevicular fluid a disintegrin and metalloproteinase 8 levels in health and periodontal disease: A clinicbiochemical study. J Pharm Bioallied Sci. 2015;7 Suppl 2:S470-473.

358. Kozarsky K, Kingsley D, Krieger M. Use of a mutant cell line to study the kinetics and function of O-linked glycosylation of low density lipoprotein receptors. Proc Natl Acad Sci U S A. 1988;85(12):4335-9.

359. Zou Z, Chung B, Nguyen T, Mentone S, Thomson B, Biemesderfer D. Linking receptor-mediated endocytosis and cell signaling: evidence for regulated intramembrane proteolysis of megalin in proximal tubule. J Biol Chem. 2004;279(33):34302-10. 
360. Mi K, Johnson GV. Regulated proteolytic processing of LRP6 results in release of its intracellular domain. J Neurochem. 2007;101(2):517-29.

361. Peschon JJ, Slack JL, Reddy P, Stocking KL, Sunnarborg SW, Lee DC, Russell WE, Castner BJ, Johnson RS, Fitzner JN, et al. An essential role for ectodomain shedding in mammalian development. Science. 1998; 282(5392):1281-4

362. Esselens CW, Malapeira J, Colome N, Moss M, Canals F, Arribas J. Metastasisassociated C4.4A, a GPI-anchored protein cleaved by ADAM10 and ADAM17. Biol Chem. 2008;389(8):1075-84.

363. Horiuchi K, Miyamoto T, Takaishi H, Hakozaki A, Kosaki N, Miyauchi Y, Furukawa M, Takito J, Kaneko H, Matsuzaki K, et al. Cell surface colonystimulating factor 1 can be cleaved by TNF-alpha converting enzyme or endocytosed in a clathrin-dependent manner. J Immunol. 2007;179(10): 6715-24.

364. Vincent B, Paitel E, Saftig P, Frobert Y, Hartmann D, De Strooper B, Grassi J, Lopez-Perez E, Checler F. The disintegrins ADAM10 and TACE contribute to the constitutive and phorbol ester-regulated normal cleavage of the cellular prion protein. J Biol Chem. 2001;276(41):37743-6.

365. Osenkowski $P$, Toth $M$, Fridman R. Processing, shedding, and endocytosis of membrane type 1-matrix metalloproteinase (MT1-MMP). J Cell Physiol. 2004; 200(1):2-10.

366. Scholler N, Fu N, Yang Y, Ye Z, Goodman GE, Hellstrom KE, Hellstrom I. Soluble member(s) of the mesothelin/megakaryocyte potentiating factor family are detectable in sera from patients with ovarian carcinoma. Proc Natl Acad Sci U S A. 1999;96(20):11531-6.

367. Onda M, Nagata S, Ho M, Bera TK, Hassan R, Alexander RH, Pastan I. Megakaryocyte potentiation factor cleaved from mesothelin precursor is a useful tumor marker in the serum of patients with mesothelioma. Clin Cancer Res. 2006;12(14 Pt 1):4225-31.

368. Hoashi T, Tamaki K, Hearing VJ. The secreted form of a melanocyte membrane-bound glycoprotein (Pmel17/gp100) is released by ectodomain shedding. FASEB J. 2010;24(3):916-30.

369. Hakulinen J, Keski-Oja J. ADAM10-mediated release of complement membrane cofactor protein during apoptosis of epithelial cells. J Biol Chem. 2006;281(30):21369-76.

370. Hakulinen J, Junnikkala S, Sorsa T, Meri S. Complement inhibitor membrane cofactor protein (MCP; CD46) is constitutively shed from cancer cell membranes in vesicles and converted by a metalloproteinase to a functionally active soluble form. Eur J Immunol. 2004;34(9):2620-9.

371. Prox J, Arnold P, Becker-Pauly C. Meprin alpha and meprin beta: Procollagen proteinases in health and disease. Matrix Biol. 2015;44-46:7-13.

372. Hahn D, Pischitzis A, Roesmann S, Hansen MK, Leuenberger B, Luginbuehl U, Sterchi EE. Phorbol 12-myristate 13-acetate-induced ectodomain shedding and phosphorylation of the human meprinbeta metalloprotease. J Biol Chem. 2003;278(44):42829-39.

373. Huang B, Sikorski R, Sampath P, Thorne SH. Modulation of NKG2D-ligand cell surface expression enhances immune cell therapy of cancer. J Immunother. 2011;34(3):289-96.

374. Fionda C, Soriani A, Zingoni A, Santoni A, Cippitelli M. NKG2D and DNAM-1 Ligands: Molecular Targets for NK Cell-Mediated Immunotherapeutic Intervention in Multiple Myeloma. Biomed Res Int. 2015;2015:178698.

375. Waldhauer I, Goehlsdorf D, Gieseke F, Weinschenk T, Wittenbrink M, Ludwig A, Stevanovic S, Rammensee HG, Steinle A. Tumor-associated MICA is shed by ADAM proteases. Cancer Res. 2008;68(15):6368-76.

376. Bazil $V$, Strominger JL. Shedding as a mechanism of down-modulation of CD14 on stimulated human monocytes. J Immunol. 1991;147(5):1567-74.

377. Thathiah A, Blobel CP, Carson DD. Tumor necrosis factor-alpha converting enzyme/ADAM 17 mediates MUC1 shedding. J Biol Chem. 2003;278(5): 3386-94.

378. Thathiah A, Carson DD. MT1-MMP mediates MUC1 shedding independent of TACE/ADAM17. Biochem J. 2004;382(Pt 1):363-73.

379. Chantry A, Gregson NA, Glynn P. A novel metalloproteinase associated with brain myelin membranes. Isolation and characterization. J Biol Chem. 1989; 264(36):21603-7.

380. Milward E, Kim KJ, Szklarczyk A, Nguyen T, Melli G, Nayak M, Deshpande D, Fitzsimmons C, Hoke A, Kerr D, et al. Cleavage of myelin associated glycoprotein by matrix metalloproteinases. J Neuroimmunol. 2008;193(1-2):140-8.

381. Lim ST, Chang A, Giuliano RE, Federoff HJ. Ectodomain shedding of nectin-1 regulates the maintenance of dendritic spine density. J Neurochem. 2012; 120(5):741-51.
382. Kim J, Lilliehook C, Dudak A, Prox J, Saftig P, Federoff HJ, Lim ST. Activitydependent alpha-cleavage of nectin-1 is mediated by a disintegrin and metalloprotease 10 (ADAM10). J Biol Chem. 2010;285(30):22919-26.

383. Schlecker E, Fiegler N, Arnold A, Altevogt P, Rose-John S, Moldenhauer G, Sucker A, Paschen A, von Strandmann EP, Textor S, et al. Metalloproteasemediated tumor cell shedding of B7-H6, the ligand of the natural killer cellactivating receptor NKp30. Cancer Res. 2014;74(13):3429-40.

384. van Erp S, van den Heuvel DM, Fujita Y, Robinson RA, Hellemons AJ, Adolfs Y, Van Battum EY, Blokhuis AM, Kuijpers M, Demmers JA, et al. Lrig2 Negatively Regulates Ectodomain Shedding of Axon Guidance Receptors by ADAM Proteases. Dev Cell. 2015;35(5):537-52.

385. Kuruppu S, Rajapakse NW, Minond D, Smith Al. Production of soluble Neprilysin by endothelial cells. Biochem Biophys Res Commun. 2014; 446(2):423-7

386. Galko MJ, Tessier-Lavigne M. Function of an axonal chemoattractant modulated by metalloprotease activity. Science. 2000;289(5483):1365-7.

387. Mechtersheimer S, Gutwein P, Agmon-Levin N, Stoeck A, Oleszewski M, Riedle S, Postina R, Fahrenholz F, Fogel M, Lemmon V, et al. Ectodomain shedding of $\mathrm{L} 1$ adhesion molecule promotes cell migration by autocrine binding to integrins. J Cell Biol. 2001;155(4):661-73.

388. Naus S, Richter M, Wildeboer D, Moss M, Schachner M, Bartsch JW. Ectodomain shedding of the neural recognition molecule $\mathrm{CHL} 1$ by the metalloprotease-disintegrin ADAM8 promotes neurite outgrowth and suppresses neuronal cell death. J Biol Chem. 2004;279(16):16083-90.

389. Brou C, Logeat F, Gupta N, Bessia C, LeBail O, Doedens JR, Cumano A, Roux P, Black RA, Israel A. A novel proteolytic cleavage involved in Notch signaling: the role of the disintegrin-metalloprotease TACE. Mol Cell. 2000;5(2):207-16.

390. Shimizu K, Chiba S, Hosoya N, Kumano K, Saito T, Kurokawa M, Kanda Y, Hamada Y, Hirai H. Binding of Delta1, Jagged1, and Jagged2 to Notch2 rapidly induces cleavage, nuclear translocation, and hyperphosphorylation of Notch2. Mol Cell Biol. 2000;20(18):6913-22.

391. Groot AJ, Habets R, Yahyanejad S, Hodin CM, Reiss K, Saftig P, Theys J, Vooijs M. Regulated proteolysis of NOTCH2 and NOTCH3 receptors by ADAM10 and presenilins. Mol Cell Biol. 2014;34(15):2822-32.

392. Cho RW, Park JM, Wolff SB, Xu D, Hopf C, Kim JA, Reddy RC, Petralia RS, Perin MS, Linden DJ, et al. mGluR1/5-dependent long-term depression requires the regulated ectodomain cleavage of neuronal pentraxin NPR by TACE. Neuron. 2008;57(6):858-71.

393. Gorodeski Gl. Estrogen decrease in tight junctional resistance involves matrix-metalloproteinase-7-mediated remodeling of occludin. Endocrinology. 2007;148(1):218-31

394. Zeng R, Li X, Gorodeski Gl. Estrogen abrogates transcervical tight junctional resistance by acceleration of occludin modulation. J Clin Endocrinol Metab. 2004:89(10):5145-55.

395. Hayashida K, Kume N, Murase T, Minami M, Nakagawa D, Inada T, Tanaka M, Ueda A, Kominami G, Kambara $H$, et al. Serum soluble lectin-like oxidized low-density lipoprotein receptor-1 levels are elevated in acute coronary syndrome: a novel marker for early diagnosis. Circulation. 2005;112(6):812-8.

396. Eugenin EA, Gamss R, Buckner C, Buono D, Klein RS, Schoenbaum EE, Calderon TM, Berman JW. Shedding of PECAM-1 during HIV infection: a potential role for soluble PECAM-1 in the pathogenesis of NeuroAIDS. J Leukoc Biol. 2006;79(3):444-52.

397. Cheng H, Yan R, Li S, Yuan Y, Liu J, Ruan C, Dai K. Shear-induced interaction of platelets with von Willebrand factor results in glycoprotein Ibalpha shedding. Am J Physiol Heart Circ Physiol. 2009;297(6):H2128-2135.

398. Gardiner EE, Andrews RK. Platelet receptor expression and shedding: glycoprotein Ib-IX-V and glycoprotein VI. Transfus Med Rev. 2014; 28(2):56-60.

399. Gardiner EE, Karunakaran D, Shen Y, Arthur JF, Andrews RK, Berndt MC. Controlled shedding of platelet glycoprotein (GP)VI and GPIb-IX-V by ADAM family metalloproteinases. J Thromb Haemost. 2007;5(7):1530-7.

400. Sakr MA, Takino T, Domoto T, Nakano H, Wong RW, Sasaki M, Nakanuma Y, Sato H. GI24 enhances tumor invasiveness by regulating cell surface membrane-type 1 matrix metalloproteinase. Cancer Sci. 2010;101(11):2368-74.

401. Wei W, Hackmann K, Xu H, Germino G, Qian F. Characterization of cisautoproteolysis of polycystin-1, the product of human polycystic kidney disease 1 gene. J Biol Chem. 2007;282(30):21729-37.

402. Tokumaru S, Higashiyama S, Endo T, Nakagawa T, Miyagawa JI, Yamamori K, Hanakawa Y, Ohmoto H, Yoshino K, Shirakata Y, et al. Ectodomain shedding 
of epidermal growth factor receptor ligands is required for keratinocyte migration in cutaneous wound healing. J Cell Biol. 2000;151(2):209-20.

403. Xu KP, Ding Y, Ling J, Dong Z, Yu FS. Wound-induced HB-EGF ectodomain shedding and EGFR activation in corneal epithelial cells. Invest Ophthalmol Vis Sci. 2004;45(3):813-20.

404. Asakura M, Kitakaze M, Takashima S, Liao Y, Ishikura F, Yoshinaka T, Ohmoto H, Node K, Yoshino K, Ishiguro H, et al. Cardiac hypertrophy is inhibited by antagonism of ADAM12 processing of HB-EGF: metalloproteinase inhibitors as a new therapy. Nat Med. 2002;8(1):35-40.

405. Yu WH, Woessner Jr JF, McNeish JD, Stamenkovic I. CD44 anchors the assembly of matrilysin/MMP-7 with heparin-binding epidermal growth factor precursor and ErbB4 and regulates female reproductive organ remodeling. Genes Dev. 2002;16(3):307-23.

406. Liu Q, Zhang J, Tran H, Verbeek MM, Reiss K, Estus S, Bu G. LRP1 shedding in human brain: roles of ADAM10 and ADAM17. Mol Neurodegener. 2009;4:17.

407. Kalinowski A, Plowes NJ, Huang Q, Berdejo-Izquierdo C, Russell RR, Russell KS. Metalloproteinase-dependent cleavage of neuregulin and autocrine stimulation of vascular endothelial cells. FASEB J. 2010;24(7):2567-75.

408. Choi DH, Hwang O, Lee KH, Lee J, Beal MF, Kim YS. DJ-1 cleavage by matrix metalloproteinase 3 mediates oxidative stress-induced dopaminergic cell death. Antioxid Redox Signal. 2011;14(11):2137-50.

409. Ludeman MJ, Zheng YW, Ishii K, Coughlin SR. Regulated shedding of PAR1 N-terminal exodomain from endothelial cells. J Biol Chem. 2004;279(18): 18592-9.

410. Dulon S, Cande C, Bunnett NW, Hollenberg MD, Chignard M, Pidard D. Proteinase-activated receptor-2 and human lung epithelial cells: disarming by neutrophil serine proteinases. Am J Respir Cell Mol Biol. 2003;28(3):339-46.

411. Yang H, Jiang D, Li W, Liang J, Gentry LE, Brattain MG. Defective cleavage of membrane bound TGFalpha leads to enhanced activation of the EGF receptor in malignant cells. Oncogene. 2000;19(15):1901-14.

412. Slomiany BL, Slomiany A. Helicobacter pylori-induced gastric mucosal TGFalpha ectodomain shedding and EGFR transactivation involves Rac1/p38 MAPK-dependent TACE activation. Inflammopharmacology. 2016;24(1):23-31.

413. Hinkle CL, Mohan MJ, Lin P, Yeung N, Rasmussen F, Milla ME, Moss ML. Multiple metalloproteinases process protransforming growth factor-alpha (proTGF-alpha). Biochemistry. 2003;42(7):2127-36.

414. Lichtenthaler SF, Dominguez DI, Westmeyer GG, Reiss K, Haass C, Saftig P, De Strooper B, Seed B. The cell adhesion protein P-selectin glycoprotein ligand-1 is a substrate for the aspartyl protease BACE1. J Biol Chem. 2003; 278(49):48713-9.

415. Nishimura D, Sakai H, Sato T, Sato F, Nishimura S, Toyama-Sorimachi N, Bartsch JW, Sehara-Fujisawa A. Roles of ADAM8 in elimination of injured muscle fibers prior to skeletal muscle regeneration. Mech Dev. 2015;135:58-67.

416. Liu PC, Liu X, Li Y, Covington M, Wynn R, Huber R, Hillman M, Yang G, Ellis D, Marando $C$, et al. Identification of ADAM10 as a major source of HER2 ectodomain sheddase activity in HER2 overexpressing breast cancer cells. Cancer Biol Ther. 2006;5(6):657-64.

417. Tse C, Gauchez AS, Jacot W, Lamy PJ. HER2 shedding and serum HER2 extracellular domain: biology and clinical utility in breast cancer. Cancer Treat Rev. 2012;38(2):133-42.

418. Kim YS, Kang HY, Kim JY, Oh S, Kim CH, Ryu CJ, Miyoshi E, Taniguchi N, Ko $\mathrm{JH}$. Identification of target proteins of $\mathrm{N}$-acetylglucosaminyl transferase $\mathrm{V}$ in human colon cancer and implications of protein tyrosine phosphatase kappa in enhanced cancer cell migration. Proteomics. 2006;6(4):1187-91.

419. Campan M, Yoshizumi M, Seidah NG, Lee ME, Bianchi C, Haber E. Increased proteolytic processing of protein tyrosine phosphatase mu in confluent vascular endothelial cells: the role of PC5, a member of the subtilisin family. Biochemistry. 1996;35(12):3797-802.

420. Burgoyne AM, Phillips-Mason PJ, Burden-Gulley SM, Robinson S, Sloan AE, Miller RH, Brady-Kalnay SM. Proteolytic cleavage of protein tyrosine phosphatase mu regulates glioblastoma cell migration. Cancer Res. 2009; 69(17):6960-8.

421. Omura A, Matsuzaki T, Mio K, Ogura T, Yamamoto M, Fujita A, Okawa K, Kitayama H, Takahashi C, Sato C, et al. RECK forms cowbell-shaped dimers and inhibits matrix metalloproteinase-catalyzed cleavage of fibronectin. J Biol Chem. 2009;284(6):3461-9.

422. Etzerodt A, Maniecki MB, Moller K, Moller HJ, Moestrup SK. Tumor necrosis factor alpha-converting enzyme (TACE/ADAM17) mediates ectodomain shedding of the scavenger receptor CD163. J Leukoc Biol. 2010;88(6):1201-5.

423. Baliova M, Betz H, Jursky F. Calpain-mediated proteolytic cleavage of the neuronal glycine transporter, GlyT2. J Neurochem. 2004;88(1):227-32.
424. Wong HK, Sakurai T, Oyama F, Kaneko K, Wada K, Miyazaki H, Kurosawa M, De Strooper B, Saftig P, Nukina N. beta Subunits of voltage-gated sodium channels are novel substrates of beta-site amyloid precursor proteincleaving enzyme (BACE1) and gamma-secretase. J Biol Chem. 2005;280(24): 23009-17.

425. Brackenbury WJ, Isom LL. Voltage-gated Na + channels: potential for beta subunits as therapeutic targets. Expert Opin Ther Targets. 2008;12(9):1191-203.

426. Hermey G, Sjogaard SS, Petersen CM, Nykjaer A, Gliemann J. Tumour necrosis factor alpha-converting enzyme mediates ectodomain shedding of Vps10p-domain receptor family members. Biochem J. 2006;395(2):285-93.

427. Zhao H, Bernardo MM, Osenkowski P, Sohail A, Pei D, Nagase H, Kashiwagi M, Soloway PD, DeClerck YA, Fridman R. Differential inhibition of membrane type 3 (MT3)-matrix metalloproteinase (MMP) and MT1-MMP by tissue inhibitor of metalloproteinase (TIMP)-2 and TIMP-3 rgulates pro-MMP-2 activation. J Biol Chem. 2004;279(10):8592-601.

428. Benaud C, Dickson RB, Lin CY. Regulation of the activity of matriptase on epithelial cell surfaces by a blood-derived factor. Eur J Biochem. 2001;268(5):1439-47.

429. Endo K, Takino T, Miyamori H, Kinsen H, Yoshizaki T, Furukawa M, Sato H. Cleavage of syndecan-1 by membrane type matrix metalloproteinase-1 stimulates cell migration. J Biol Chem. 2003;278(42):40764-70.

430. Asundi VK, Erdman R, Stahl RC, Carey DJ. Matrix metalloproteinasedependent shedding of syndecan-3, a transmembrane heparan sulfate proteoglycan, in Schwann cells. J Neurosci Res. 2003;73(5):593-602.

431. Schulz JG, Annaert W, Vandekerckhove J, Zimmermann P, De Strooper B, David G. Syndecan 3 intramembrane proteolysis is presenilin/gammasecretase-dependent and modulates cytosolic signaling. J Biol Chem. 2003; 278(49):48651-7.

432. Tseng WY, Huang YS, Chiang NY, Chou YP, Wu YJ, Luo SF, Kuo CF, Lin KM Lin HH. Increased soluble CD4 in serum of rheumatoid arthritis patients is generated by matrix metalloproteinase (MMP)-like proteinases. PLoS One. 2013;8(5):e63963.

433. Freimuth WW, Esselman WJ, Miller HC. Release of thy-1.2 and thy-1.1 from lymphoblastoid cells: partial characterization and antigenicity of shed material. J Immunol. 1978;120(5):1651-8.

434. Almqvist P, Carlsson SR. Characterization of a hydrophilic form of Thy-1 purified from human cerebrospinal fluid. J Biol Chem. 1988;263(25):12709-15.

435. Hagood JS, Prabhakaran P, Kumbla P, Salazar L, MacEwen MW, Barker $T H$, Ortiz LA, Schoeb T, Siegal GP, Alexander CB, et al. Loss of fibroblast Thy-1 expression correlates with lung fibrogenesis. Am J Pathol. 2005; 167(2):365-79.

436. Belaaouaj AA, Li A, Wun TC, Welgus HG, Shapiro SD. Matrix metalloproteinases cleave tissue factor pathway inhibitor. Effects on coagulation. J Biol Chem. 2000:275(35):27123-8.

437. Ali N, Knauper V. Phorbol ester-induced shedding of the prostate cancer marker transmembrane protein with epidermal growth factor and two follistatin motifs 2 is mediated by the disintegrin and metalloproteinase- 17 . J Biol Chem. 2007:282(52):37378-88.

438. Rose AA, Annis MG, Dong Z, Pepin F, Hallett M, Park M, Siegel PM. ADAM10 releases a soluble form of the GPNMB/Osteoactivin extracellular domain with angiogenic properties. PLoS One. 2010;5(8):e12093.

439. Hoashi T, Sato S, Yamaguchi Y, Passeron T, Tamaki K, Hearing VJ. Glycoprotein nonmetastatic melanoma protein b, a melanocytic cell marker, is a melanosome-specific and proteolytically released protein. FASEB J. 2010; 24(5):1616-29.

440. Afar DE, Vivanco I, Hubert RS, Kuo J, Chen E, Saffran DC, Raitano AB, Jakobovits A. Catalytic cleavage of the androgen-regulated TMPRSS2 protease results in its secretion by prostate and prostate cancer epithelia. Cancer Res. 2001;61(4):1686-92.

441. Lum L, Wong BR, Josien R, Becherer JD, Erdjument-Bromage H, Schlondorff J, Tempst P, Choi Y, Blobel CP. Evidence for a role of a tumor necrosis factor-alpha (TNF-alpha)-converting enzyme-like protease in shedding of TRANCE, a TNF family member involved in osteoclastogenesis and dendritic cell survival. J Biol Chem. 1999;274(19):13613-8.

442. Hikita A, Yana I, Wakeyama H, Nakamura M, Kadono Y, Oshima Y, Nakamura K, Seiki M, Tanaka S. Negative regulation of osteoclastogenesis by ectodomain shedding of receptor activator of NF-kappaB ligand. J Biol Chem. 2006;281(48):36846-55.

443. Wauman J, De Ceuninck L, Vanderroost N, Lievens S, Tavernier J. RNF41 (Nrdp1) controls type 1 cytokine receptor degradation and ectodomain shedding. J Cell Sci. 2011;124(Pt 6):921-32. 
444. Muck C, Herndler-Brandstetter D, Micutkova L, Grubeck-Loebenstein B, Jansen-Durr P. Two functionally distinct isoforms of TL1A (TNFSF15) generated by differential ectodomain shedding. J Gerontol Ser A Biol Med Sci. 2010;65(11):1165-80.

445. Mitsiades N, Yu WH, Poulaki V, Tsokos M, Stamenkovic I. Matrix metalloproteinase-7-mediated cleavage of Fas ligand protects tumor cells from chemotherapeutic drug cytotoxicity. Cancer Res. 2001;61(2):577-81.

446. Fourie AM, Coles F, Moreno V, Karlsson L. Catalytic activity of ADAM8, ADAM15, and MDC-L (ADAM28) on synthetic peptide substrates and in ectodomain cleavage of CD23. J Biol Chem. 2003;278(33):30469-77.

447. Tinazzi E, Barbieri A, Rigo A, Patuzzo G, Beri R, Gerli R, Argentino G, Puccetti A, Lunardi C. In rheumatoid arthritis soluble CD30 ligand is present at high levels and induces apoptosis of CD30(+)T cells. Immunol Lett. 2014;161(2):236-40.

448. Contin C, Pitard V, Itai T, Nagata S, Moreau JF, Dechanet-Merville J. Membrane-anchored CD40 is processed by the tumor necrosis factor-alphaconverting enzyme. Implications for CD40 signaling. J Biol Chem. 2003; 278(35):32801-9.

449. Koolwijk P, Sidenius N, Peters E, Sier CF, Hanemaaijer R, Blasi F, van Hinsbergh WW. Proteolysis of the urokinase-type plasminogen activator receptor by metalloproteinase-12: implication for angiogenesis in fibrin matrices. Blood. 2001;97(10):3123-31.

450. Guzman-Hernandez ML, Potter G, Egervari K, Kiss JZ, Balla T. Secretion of VEGF-165 has unique characteristics, including shedding from the plasma membrane. Mol Biol Cell. 2014;25(7):1061-72.

451. Funatsu N, Miyata S, Kumanogoh H, Shigeta M, Hamada K, Endo Y, Sokawa Y, Maekawa S. Characterization of a novel rat brain glycosylphosphatidylinositol-anchored protein (Kilon), a member of the IgLON cell adhesion molecule family. J Biol Chem. 1999;274(12):8224-30.

452. Zhang Z, Henzel WJ. Signal peptide prediction based on analysis of experimentally verified cleavage sites. Protein Sci. 2004;13(10):2819-24.

453. Van Damme P, Martens L, Van Damme J, Hugelier K, Staes A, Vandekerckhove J, Gevaert K. Caspase-specific and nonspecific in vivo protein processing during Fas-induced apoptosis. Nat Methods. 2005;2(10):771-7.

454. Gougos A, Letarte M. Primary structure of endoglin, an RGD-containing glycoprotein of human endothelial cells. J Biol Chem. 1990;265(15):8361-4.

455. Eiffert H, Quentin E, Wiederhold M, Hillemeir S, Decker J, Weber M, Hilschmann N. Determination of the molecular structure of the human free secretory component. Biol Chem Hoppe Seyler. 1991;372(2):119-28.

456. Suzuki K, Kusumoto H, Deyashiki Y, Nishioka J, Maruyama I, Zushi M, Kawahara S, Honda G, Yamamoto S, Horiguchi S. Structure and expression of human thrombomodulin, a thrombin receptor on endothelium acting as a cofactor for protein C activation. EMBO J. 1987;6(7):1891-7.

457. Ullrich A, Gray A, Tam AW, Yang-Feng T, Tsubokawa M, Collins C, Henzel W, Le Bon T, Kathuria S, Chen E, et al. Insulin-like growth factor I receptor primary structure: comparison with insulin receptor suggests structural determinants that define functional specificity. EMBO J. 1986;5(10):2503-12.

458. Watanabe E, Maeda N, Matsui F, Kushima Y, Noda M, Oohira A. Neuroglycan $C$, a novel membrane-spanning chondroitin sulfate proteoglycan that is restricted to the brain. J Biol Chem. 1995;270(45):26876-82.

459. Pimenta AF, Zhukareva V, Barbe MF, Reinoso BS, Grimley C, Henzel W, Fischer I, Levitt P. The limbic system-associated membrane protein is an Ig superfamily member that mediates selective neuronal growth and axon targeting. Neuron. 1995;15(2):287-97.

460. Orr HT, de Castro JA L, Parham P, Ploegh HL, Strominger JL. Comparison of amino acid sequences of two human histocompatibility antigens, HLA-A2 and HLA-B7: location of putative alloantigenic sites. Proc Natl Acad Sci U S A. 1979;76(9):4395-9.

461. Comu S, Weng W, Olinsky S, Ishwad P, Mi Z, Hempel J, Watkins S, Lagenaur CF, Narayanan V. The murine P84 neural adhesion molecule is SHPS-1, a member of the phosphatase-binding protein family. J Neurosci. 1997;17(22):8702-10.

462. Gevaert K, Goethals M, Martens L, Van Damme J, Staes A, Thomas GR, Vandekerckhove J. Exploring proteomes and analyzing protein processing by mass spectrometric identification of sorted N-terminal peptides. Nat Biotechnol. 2003;21(5):566-9.

463. Shinkai-Ouchi F, Koyama S, Ono Y, Hata S, Ojima K, Shindo M, duVerle D, Ueno M, Kitamura F, Doi N, et al. Predictions of Cleavability of Calpain Proteolysis by Quantitative Structure-Activity Relationship Analysis Using Newly Determined Cleavage Sites and Catalytic Efficiencies of an Oligopeptide Array. Mol Cell Proteomics. 2016;15(4):1262-80.

464. Ahram M, Strittmatter EF, Monroe ME, Adkins JN, Hunter JC, Miller JH, Springer DL. Identification of shed proteins from Chinese hamster ovary cells: application of statistical confidence using human and mouse protein databases. Proteomics. 2005;5(7):1815-26.

465. Faca VM, Ventura AP, Fitzgibbon MP, Pereira-Faca SR, Pitteri SJ, Green AE, Ireton $\mathrm{RC}$, Zhang $\mathrm{Q}$, Wang $\mathrm{H}$, O'Briant $\mathrm{KC}$, et al. Proteomic analysis of ovarian cancer cells reveals dynamic processes of protein secretion and shedding of extra-cellular domains. PLoS One. 2008;3(6):e2425.

466. Eichelbaum K, Krijgsveld J. Rapid temporal dynamics of transcription, protein synthesis, and secretion during macrophage activation. Mol Cell Proteomics. 2014;13(3):792-810.

467. Feizi A, Banaei-Esfahani A, Nielsen J. HCSD: the human cancer secretome database. Database (Oxford). 2015;2015:bav051.

468. Li SJ, Peng M, Li H, Liu BS, Wang C, Wu JR, Li YX, Zeng R. Sys-BodyFluid: a systematical database for human body fluid proteome research. Nucleic Acids Res. 2009;37(Database issue):D907-912.

469. Chen Y, Zhang Y, Yin Y, Gao G, Li S, Jiang Y, Gu X, Luo J. SPD-a web-based secreted protein database. Nucleic Acids Res. 2005;33(Database issue):D169-173.

470. Sprenger J, Lynn Fink J, Karunaratne S, Hanson K, Hamilton NA, Teasdale RD. LOCATE: a mammalian protein subcellular localization database. Nucleic Acids Res. 2008:36(Database issue):D230-233.

\section{Submit your next manuscript to BioMed Central and we will help you at every step:}

- We accept pre-submission inquiries

- Our selector tool helps you to find the most relevant journal

- We provide round the clock customer support

- Convenient online submission

- Thorough peer review

- Inclusion in PubMed and all major indexing services

- Maximum visibility for your research

Submit your manuscript at www.biomedcentral.com/submit
Biomed Central 